\title{
Paleoenvironmental context of the Middle Stone Age record from Karungu, Lake Victoria Basin, Kenya, and its implications for human and faunal dispersals in East Africa
}

J. Tyler Faith ${ }^{\mathrm{a},{ }^{*}}$, Christian A. Tryon ${ }^{\mathrm{b}}$, Daniel J. Peppe ${ }^{\mathrm{c}}$, Emily J. Beverly ${ }^{\mathrm{c}}$, Nick Blegen $^{d}$, Scott Blumenthal ${ }^{e}$, Kendra L. Chritz $^{f}$, Steven G. Driese ${ }^{c}$, David Patterson ${ }^{g}$

a School of Social Science, University of Queensland, Brisbane, QLD 4072, Australia

b Department of Anthropology, Harvard University, Peabody Museum, 11 Divinity Ave, Cambridge, MA 02138, USA

c Terrestrial Paleoclimatology Research Group, Department of Geology, Baylor University, Waco, TX 76798, USA

d Department of Anthropology, University of Connecticut, Storrs, CT 06269, USA

e Department of Anthropology, The Graduate Center, City University of New York, New York, NY 10016, USA

f Department of Biology, University of Utah, Salt Lake City, UT 84112

g Center for the Advanced Study of Hominid Paleobiology, Department of Anthropology, The George Washington University, Washington, DC 20052, USA

${ }^{*}$ Corresponding author.

E-mail address: j.faith@uq.edu.au (J.T. Faith).

Keywords: Modern human origins; Obsidian sourcing; Stable isotopes 


\section{Abstract}

The opening and closing of the equatorial East African forest belt during the Quaternary is thought to have influenced the biogeographic histories of early modern humans and fauna, although precise details are scarce due to a lack of archaeological and paleontological records associated with paleoenvironmental data. With this in mind, we provide a description and paleoenvironmental reconstruction of the Late Pleistocene Middle Stone Age (MSA) artifact- and fossil-bearing sediments from Karungu, located along the shores of Lake Victoria in western Kenya. Artifacts recovered from surveys and controlled excavations are typologically MSA and include points, blades, and Levallois flakes and cores, as well as obsidian flakes similar in geochemical composition to documented sources near Lake Naivasha (250 $\mathrm{km}$ east). A combination of sedimentological, paleontological, and stable isotopic evidence indicates a semi-arid environment characterized by seasonal precipitation and the dominance of $\mathrm{C}_{4}$ grasslands, likely associated with a substantial reduction in Lake Victoria. The well-preserved fossil assemblage indicates that these conditions are associated with the convergence of historically allopatric ungulates from north and south of the equator, in agreement with predictions from genetic observations. Analysis of the East African MSA record reveals previously unrecognized northsouth variation in assemblage composition that is consistent with episodes of population fragmentation during phases of limited dispersal potential. The grasslandassociated MSA assemblages from Karungu and nearby Rusinga Island are characterized by a combination of artifact types that is more typical of northern sites. This may reflect the dispersal of behavioral repertoires-and perhaps human populations_during a paleoenvironmental phase dominated by grasslands. 


\section{Introduction}

Fossil evidence from East Africa provides the earliest known specimens attributed to Homo sapiens, dating to 195 ka (thousands of years ago) (McDougall et al., 2005; Brown et al., 2012). These early humans later diverged into multiple genetically (Campbell and Tishkoff, 2010) and morphologically diverse (Creveceour et al., 2009; Gunz et al., 2009; Harvati et al., 2013; Tryon et al., 2015) populations during the Late Pleistocene (126 to $12 \mathrm{ka}$ ), likely reflecting complex phases of population dispersal and vicariance across Africa (Campbell and Tishkoff, 2010;

Soares et al., 2012; Rito et al., 2013). This biological diversity among early modern humans is accompanied by substantial behavioral diversity, with the Middle Stone Age (MSA) archaeological record of East Africa ( 285 to $50 \mathrm{ka}$ ) characterized by exceptional variability and only rare cases of geographic or temporal patterning (Tryon and Faith, 2013).

Understanding the mechanisms underlying the diversity of early human populations and their dispersals within and out of Africa remains a fundamental challenge of human origins research. A commonly proposed mechanism is environmental change, which may have mediated population distributions and demographics (Scholz et al., 2007; Eriksson et al., 2012; Rito et al., 2013), the opening and closing of biogeographic barriers (Vaks et al., 2007; Cowling et al., 2008; Carto et al., 2009; Compton, 2011; Faith et al., in press), and behavioral adaptations to resource availability (Ambrose and Lorenz, 1990; McCall, 2007; Marean, 2010). Of particular relevance to East Africa, Cowling et al. (2008) propose that the repeated opening and closing of the equatorial East African forest belt throughout the Quaternary, mediated by changes in rainfall and atmospheric $\mathrm{CO}_{2}$ 
concentrations, potentially played a key role in the dispersals of humans and fauna. Their model is supported by genetic evidence from contemporary fauna, with a broad range of widely distributed vertebrate species, including wildebeest (Connochaetes taurinus), hartebeest (Alcelaphus buselaphus), waterbuck (Kobus ellipsiprymnus), giraffe (Giraffa camelopardalis), ostrich (Struthio camelus), and many others, showing pronounced differentiation between populations from north and south of the equator (Dehgani et al., 2008; Miller et al., 2011; Lorenzen et al., 2012). This genetic structuring is believed to represent the legacy of populations with geographic ranges that were continuous during dry climatic phases of expanded grassland cover but fragmented north and south of the equator during wetter phases associated with an expansion of forest cover (Lorenzen et al., 2012). However, the precise role of this dispersal mechanism in the biogeographic histories of humans and fauna remains poorly resolved, largely due to a lack of empirical evidence and difficulties in relating local signals from archaeological and fossil records to regional or global climate records (Behrensmeyer, 2006; Blome et al., 2012). Resolving this situation from the East African homeland of fossil Homo sapiens requires new archaeological and paleontological evidence associated with detailed paleoenvironmental records.

Our aim here is to provide such evidence stemming from our ongoing investigations of MSA artifact- and fossil-bearing sediments at Karungu, in the Lake Victoria Basin of Kenya (Fig. 1). This study describes (1) the history of paleoanthropological research at Karungu, (2) the geological context of the Pleistocene sediments, (3) the MSA archaeological record from Karungu, and (4) the paleoenvironmental implications of the associated faunal assemblage, including stable isotopic analysis of bovid and East African mole rat (Tachyoryctes splendens) tooth enamel. We use these data, together with an analysis of variation in the Late 
Pleistocene MSA record of East Africa, to explore the potential role of an equatorial dispersal barrier in the biogeographic histories of early modern humans and fauna.

\section{The Lake Victoria Basin}

Straddling the equator in East Africa, Lake Victoria is the largest African lake by surface area $\left(66,400 \mathrm{~km}^{2}\right.$; Adams, 1996) and represents a significant barometer of Quaternary paleoenvironmental change. Because water input is determined primarily by rainfall directly over its surface, rather than inflow from rivers and streams, Lake Victoria is highly sensitive to changes in precipitation (Broecker et al., 1998; Nicholson, 1998; Milly, 1999; Bootsma and Hecky, 2003), with historic records from the last 200 years documenting lake level fluctuations of $\sim 4 \mathrm{~m}$ in response to precipitation variability (Nicholson, 1989). The lake is also very shallow (maximum depth $<80 \mathrm{~m}$ ), which means that relatively small changes in lake level translate to massive shifts in lake surface area.

Although precise details are scarce prior to the Last Glacial Maximum (LGM), geological evidence documents massive fluctuations in lake level and surface area over the $\geq 400,000$ year history of the lake (Temple, 1966; Johnson et al., 1996;

Stager et al., 2002, 2011; Stager and Johnson, 2008; Tryon et al., 2014). Seismic profiles and lake cores document at least four desiccation events (Johnson et al., 1996, 2000; Stager and Johnson, 2008), the two most recent of which correspond to extreme aridity during Heinrich Event 1 between 17 to 16 ka and a subsequent arid phase between 15 to 14 ka (Stager et al., 2011); the other desiccation surfaces correspond to undated phases of previous aridity. Three horizontally bedded terraces around the circumference of Lake Victoria at $18 \mathrm{~m}, 10-12 \mathrm{~m}$, and $3 \mathrm{~m}$ 
above modern lake level indicate previous high-stands (Kent, 1942; Doornkamp and Temple, 1966; Temple, 1966), which were caused by increased precipitation (Johnson et al., 2000; Beuning et al., 2002), changes to the lake's drainage due to regional tectonics (Doornkamp and Temple, 1966; Temple, 1966), or a combination of the two.

The repeated expansion and contraction of Lake Victoria is known to have had an important influence on biotic communities. Evidence from pollen cores (Kendall, 1969), geochemical proxies for vegetation cover (Talbot and Laerdal, 2000; Talbot et al., 2006), and fossil mammals (Tryon et al., 2012, 2014) show that reductions in lake level were associated with a dominance of grasslands, in contrast to the evergreen bushland, thicket, and forest habitats historically present in the region (White, 1983; van Breugel et al., 2012). This expansion and contraction of grasslands and forests potentially facilitated the dispersal of flora and fauna across the Lake Victoria Basin, as indicated by the modern distribution of species in the region (White, 1983; Kingdon, 1990; Wronski and Hausdorf, 2008). Together, the evidence for dynamic vegetation change and species dispersals suggests that the Lake Victoria Basin represents an ideal natural laboratory to explore the influence of environmental change on the dispersal histories of early modern humans and associated fauna.

\section{Background to Karungu}

Karungu is located along the shores of Lake Victoria in southwest Kenya ($\left.0.844^{\circ} \mathrm{S}, 34.157^{\circ} \mathrm{E}\right), 50 \mathrm{~km}$ south of the well-known Miocene (e.g., Le Gros Clark and Leakey, 1950; Van Couvering, 1972; Leakey, 1974; Andrews, 1981; Pickford, 1986; 
Teaford et al., 1988; Walker and Teaford, 1988; Peppe et al., 2009; Michel et al., 2014) and Pleistocene (Pickford and Thomas, 1984; Tryon et al., 2010, 2012, 2014;

Faith et al., 2011, in press) localities on Rusinga and Mfangano Island (Fig. 1) and $65 \mathrm{~km}$ southwest of the Miocene-to-Pleistocene deposits on the Homa Peninsula (e.g., Oswald, 1914; Andrews, 1916; Pickford, 1984; Behrensmeyer et al., 1995; Ditchfield et al., 1999). Although much of the landscape around Karungu is now under cultivation, the historic vegetation included evergreen bushland and thicket in the immediate area, grading to woodlands and more humid Afromontane rainforests further inland (White, 1983; van Breugel et al., 2012). Average annual rainfall at nearby Mbita (45 km north) ranges from 1,000 to 1,400 mm (Fullinger et al., 2004; Hijmans et al., 2005). The large mammal herbivores in the region historically included African buffalo (Syncerus caffer), bushbuck (Tragelaphus scriptus), duiker (Sylvicapra grimmia), Bohor reedbuck (Redunca redunca), waterbuck (Kobus ellipsiprymnus), impala (Aepyceros melampus), topi (Damaliscus lunatus), hartebeest (Alcelaphus buselaphus), oribi (Ourebia ourebi), roan antelope (Hippotragus equinus), giraffe (Giraffa camelopardalis), bushpig (Potamochoerus larvatus), black rhinoceros (Diceros bicornis), and elephant (Loxodonta africana) (Allsopp and Baldry, 1972; Kimanzi, 2011).

Karungu is among the earliest documented paleontological localities in Kenya, with fossils first discovered in the region in 1909 (see Andrews, 1981) and published two years later (Andrews, 1911). Subsequent fieldwork directed by Oswald focused on the rich Miocene fossil sites (Andrews, 1914; Newton, 1914; Oswald, 1914) and incidentally documented the presence of lithic artifacts "of a Neolithic character" lying on the surface of Miocene deposits (Oswald, 1914:136). Since then, the Miocene deposits at Karungu have been intermittently studied by L.S.B. Leakey, Andrews, 
Pickford, and McNulty and colleagues (Andrews, 1981; Pickford, 1984; Lehmann et al., 2014; McNulty et al., 2014).

During the 1930s, Archdeacon W.E. Owen conducted the first exploration of the Quaternary sediments at Karungu (Owen, 1937, 1938, 1939). In an unpublished manuscript, he notes the discovery of in situ human remains from up to six individuals from a site known as Ngira (Figs. 1 and 2), in addition to the presence of fossil fauna and artifacts referred to as Kenyan Aurignacian (= Later Stone Age, LSA), Levallois (= Middle Stone Age, MSA), and Acheulean (Owen, 1937). The human remains are associated with LSA artifacts and evidently with pottery; the fossils curated at the National Museum of Kenya (NMK) in Nairobi are weakly mineralized, further indicating a more recent age than the material described in this study. Many of the human remains collected by Owen have since been lost, some perhaps during the bombing of the Royal College of Surgeons in London during World War II, where Sir Arthur Keith and T.D. McCown studied and described some of the remains (noted in Owen, 1937). Subsequent papers published by Owen $(1938,1939)$ also note the presence of rolled Acheulean hand-axes, as well as Kombewa flakes and cores from probable channel deposits at Ngira and Aringo.

Pickford's (1984) investigations at Karungu proved to be the most useful for guiding the present research. In his survey of paleontological sites from western Kenya, he mapped 12 localities with exposure of Pleistocene deposits (Fig. 1) that unconformably overlie the Miocene sequence. Pickford (1984) reported from these Pleistocene deposits the presence of MSA artifacts and fossil fauna, including an assortment of extant bovids, equids, and suids, which led him to assign a probable Late Pleistocene age to the deposits. From 2011-2013, we conducted investigations of the deposits mapped by Pickford (1984). This included systematic pedestrian 
surveys, supplemented by controlled archaeological excavations and geological trenching. We provide below the first detailed description of the geology, MSA archaeology, and paleontology of Karungu.

\section{Methods}

Field methods

Pedestrian surveys were conducted at all Pleistocene exposures at Karungu from 2011-2013. Of the 12 Pleistocene localities mapped by Pickford (1984), we were able to collect artifacts and fossils from seven: Aoch Nyasaya, Aringo, Kachuku, Kisaaka, Ngira, Obware, and Onge (Fig. 1). The remaining localities are presently under cultivation and no longer exposed (e.g., Owich) or are now commercial or residential centers that appear to have been destroyed by recent construction (e.g., Sori).

The primary archaeological objective of the survey was to identify the broad archaeological taxonomic units (e.g., ESA, MSA, LSA) present through the Karungu Pleistocene sequence. At all localities, general collection of lithic artifacts documented during the survey was restricted only to those specimens that were diagnostic of these industries ( $n=63$ specimens total). This collection was supplemented by systematic collections of all lithic material by surface crawls from six 24-25 $\mathrm{m}^{2}$ gridded areas at Kisaaka, Obware, and Aringo (Fig. 3; Table 1). These grids were selected to maximize artifact samples and were established at or near the base of actively eroding profiles containing one or more marker tephra deposits to provide stratigraphic control (Fig. 4). 
To characterize the in situ archaeological material, a test excavation was conducted at the Aringo 3 site in 2013 (Figs. 1 and 3), where a small geological trench uncovered numerous artifacts. A controlled test excavation of $5 \mathrm{~m}^{2}$ was set up adjacent to the trench, and excavated according to arbitrary $10-\mathrm{cm}$ levels within discernible stratigraphic units. All sediment was sieved through 1/8-inch mesh and in situ artifacts were plotted in three-dimensions using a total station linked to a laptop computer running EDM for Windows excavation software.

Following our previous collections on Rusinga and Mfangano islands (Tryon et al., 2010, 2012), the collection of fauna emphasized the recovery of taxonomically informative specimens, including all cranial and dental remains, bovid horn cores, ruminant astragali and metapodials, and all specimens belonging to primates or carnivores. Microfaunal remains were recovered in abundance from the general surface collection at Kisaaka, with smaller collections from Aoch Nyasaya, Aringo, and Obware. Microfaunal recovery was enhanced at Kisaaka by screening surface sediments from an approximately $10 \mathrm{~m}^{2}$ area through $1-\mathrm{mm}$ mesh at three sites: Zebra Tooth Gulley (ZTG), Rodent Carbonate Site (RCS), and Main (Fig. 3).

\section{Obsidian geochemistry}

Obsidian flakes were documented in our excavation at Aringo 3 (LVP2014-31) and collected from the surface at Kisaaka (LVP2014-32). The nearest documented obsidian sources are in the Eastern Rift Valley $\sim 250 \mathrm{~km}$ to the east (Merrick and Brown, 1984; Brown et al., 2013). To identify the potential sources of these obsidian artifacts, we characterized their geochemistry by wavelength dispersive electron microprobe analysis conducted on a Cameca SX-50 in the Department of Geology 
and Geophysics at the University of Utah. Analytical conditions follow the recent detailed survey of Kenyan obsidian sources provided by Brown et al. (2013).

Isotope analysis

To enhance our paleoecological interpretations of the fossil mammals, we conducted a stable isotope analysis of fossil bovid ( $n=20$ specimens) and rodent tooth enamel ( $n=17$ specimens). Modern bovids exhibit a wide range of habitat preferences and are particularly useful for reconstructing paleoenvironments in East Africa (e.g., Gentry, 1970; Vrba, 1980; Scott, 1985; Cerling et al., 2003; Plummer et al., 2009), and we sampled teeth from the dominant tribes present in the assemblage (Alcelaphini, Antilopini, Bovini, and Reduncini). Due to their smaller home ranges, micromammals provide a more localized ecological signal than the wider-ranging bovids that relates to locally available microenvironments (Kimura et al., 2013; Symes et al., 2013). Because carbon isotope values relate to the diet of mammalian herbivores, these data can be used to determine the presence of $\mathrm{C}_{4}$ grasses and the heterogeneity of available food resources at varying spatial scales (e.g., Cerling et al., 2003; Codron et al., in press).

Bovid teeth were selected from the surface collections, photographed, and sampled along broken edges using a Dremel tool and diamond drill bit, following the destructive sampling procedures outlined by the NMK. Enamel samples were prepared and analyzed at the University of Utah. Enamel powders were treated with 0.1 M buffered acetic acid for 30 minutes to remove labile carbonates (Lee-Thorp and van Der Merwe, 1987; Koch et al., 1997). Following acid treatment, samples were rinsed three times with distilled water and dried at $60^{\circ} \mathrm{C}$ overnight. Samples 
were weighed into silver capsules and dried under vacuum at $200^{\circ} \mathrm{C}$ for two hours prior to analysis. Samples were then digested in a common phosphoric acid bath at $90^{\circ} \mathrm{C}$ for 15 minutes and analyzed for $\delta^{13} \mathrm{C}$ on a Finnigan MAT 252 coupled to a Carboflo dual-inlet carbonate device. Stable isotope ratios are reported as $\delta$ values relative to the international carbon isotope standard, Vienna Pee Dee Belemnite (VPDB), using the standard per mil (\%o) notation, where $\delta^{13} \mathrm{C}=\left(\mathrm{R}_{\text {sample }} / \mathrm{R}_{\text {standard }}-1\right) \mathrm{x}$ 1000 , and $R_{\text {sample }}$ and $R_{\text {standard }}$ are the ${ }^{13} \mathrm{C} /{ }^{12} \mathrm{C}$ ratios of the sample and standard, respectively. Standard deviation of an internal carbonate standard (Carrara marble) was $+/-0.1 \%$.

Microfaunal remains were selected from the surface collections and exported to the Department of Earth and Planetary Sciences at Johns Hopkins University, following NMK guidelines. Isotopic analyses of the microfauna were performed at Johns Hopkins University, following approximately the same procedure described above for the bovids. All incisors were photographed prior to sampling with a Dremel Tool and diamond drill bit. Enamel powder was treated for 15 minutes with $3 \% \mathrm{H}_{2} \mathrm{O}_{2}$ and rinsed three times with distilled water prior to the 15 minute treatment with $0.1 \mathrm{M}$ buffered acetic acid. Following this treatment, samples were then rinsed three times in distilled water and dried overnight at $60^{\circ} \mathrm{C}$. Samples were loaded in silver capsules and then digested in a phosphoric acid bath at $90^{\circ} \mathrm{C}$ for 10 minutes and analyzed for $\delta^{13} \mathrm{C}$ on a Thermo MAT 253 mass spectrometer. Standard deviation of three internal carbonate standards was $0.32 \%$.

Dietary designations for bovids are based on estimated consumption of $\mathrm{C}_{4}$ plants (tropical grasses) and $\mathrm{C}_{3}$ plants (trees, shrubs, herbs), which is calculated using a hypothetical $100 \% \mathrm{C}_{4}$ diet and an isotope enrichment $\left(\varepsilon^{*}\right)$ between diet and herbivore tooth enamel of $14.1 \%$ (Cerling and Harris, 1999). Estimated carbon 
isotope composition of tooth enamel for a $100 \% \mathrm{C}_{4}$ diet is based on the average isotopic value of modern $\mathrm{C}_{4}$ plants in eastern and central Africa $(-12.9 \%, n=764$;

Cerling et al., 2011). Following Garret et al. (in press), changes in atmospheric $\mathrm{CO}_{2}$ between modern environments and the Late Pleistocene (Tipple et al., 2010) were accounted for by adding $1.6 \%$ to the modern average $\delta^{13} \mathrm{C}$ of $\mathrm{C}_{4}$ plants. Although we estimate the percentage of $\mathrm{C}_{4}$ vegetation consumption by the rodents in our sample, we do not designate specific diet categories (as with bovids) due to an incomplete understanding of how stable isotopes relate in a generalizable way to the consumption of different food resources among their extant relatives (Symes et al., 2013; Codron et al., in press).

\section{Geological context}

Although previous researchers have mapped the Pleistocene exposures at Karungu (Owen, 1937; Pickford, 1984), there are no formal descriptions of the lithologies of these deposits or detailed stratigraphic measurements. The Pleistocene deposits are best exposed at Kisaaka, Aringo, Onge, Aoch Nyasaya, and Obware. These form the basis of our geological description. At Kachuku and Ngira, the Pleistocene deposits are poorly exposed and have undergone too much erosion for any geological interpretation.

The Pleistocene deposits of Karungu are discontinuously exposed over an area of $\sim 40 \mathrm{~km}^{2}$ and are most commonly preserved at elevations $\sim 15-65 \mathrm{~m}$ above modern Lake Victoria (Fig. 1). Pleistocene sediment thickness at Karungu varies between sites and ranges from 3.5 to $10.5 \mathrm{~m}$ of deposit. The deposits overlie a relatively complex eroded topography of Miocene bedrock (Oswald, 1914; Pickford, 
1984). The entire sedimentary sequence is exposed at Kisaaka and has been used to develop a composite stratigraphy of the Pleistocene deposits at Karungu (Fig. 4). Different sections of the Kisaaka composite stratigraphic sequence can be correlated to fossil- and artifact-bearing exposures at other sites in Karungu using tephrostratigraphy (Blegen et al., in review; Supplementary Online Material [SOM]).

The Pleistocene sedimentary sequence at Karungu comprises fluvial deposits, paleosols, and variably reworked tephra (Fig. 4). At the base of the sequence is a conglomerate of varying thickness that is overlain by three paleosols intercalated with tephra deposits. Field observations indicate that the basal paleosol is a paleo-Vertisol with pedogenic slickensides, gilgai topography, and wedge peds that formed as the soil expanded and contracted during wet and dry seasons (Beverly et al., in press). These vertic features indicate precipitation seasonality and a period of landscape stability of at least 0.5 to 2 kyr (Mermut et al., 1996; Buol et al., 2003; Southard et al., 2011). Where exposed, this basal paleo-Vertisol is relatively similar in composition and character across the Karungu landscape. The upper two paleosols are identified as tuffaceous paleo-Inceptisols, with angular blocky ped structures and illuviated clay. These paleo-Inceptisols indicate a considerably shorter period of landscape stability than the basal paleo-Vertisol. An influx of tephra into the drainage basin likely through a combination of airfall events and fluvial reworking of ash affected the types of soil forming on the landscape (i.e., between the basal paleo-Vertisol and the upper two paleo-Inceptisols). Between the paleosols are a series of tephra deposits that have been correlated to Aringo, Onge, Aoch Nyasaya, and Obware based on the geochemical signature of the volcanic glass, as well as to the Late Pleistocene exposures on Rusinga and Mfangano Islands (Blegen et al., in review; SOM). 
In terms of sedimentology and lithology, the Pleistocene exposures at Karungu are similar and stratigraphically consistent with the Pleistocene deposits at Rusinga and Mfangano Islands to the north (Tryon et al., 2010, 2012, 2014). The correlation of the series of tephra deposits at Karungu, Rusinga, and Mfangano, indicates that all three regions are temporally equivalent (Blegen et al., in review; SOM). While the deposits at Karungu, Rusinga, and Mfangano are similar, there are some sedimentological differences. In particular, the deposits on Rusinga and Mfangano are more fluvially dominated and the paleosols are all poorly developed (Tryon et al., 2010, 2012, 2014), suggesting less stable depositional environments than those at Karungu. These differences are probably due to the proximity of the Pleistocene deposits on Rusinga and Mfangano to local topographic highs on the landscape (Tryon et al., 2014). Despite differences in pedogenic development, many of the paleosols at Karungu, Rusinga, and Mfangano have vertic features suggesting similar climatic conditions (i.e., seasonal precipitation) across the region.

Direct age estimates for the Pleistocene deposits at Karungu are provided by accelerator mass spectrometry (AMS) radiocarbon dates on surface-collected ostrich eggshell fragments from Kisaaka and Aringo (below the Nyamita tuff in Fig. 4). The age estimates for Kisaaka are 46,413 $\pm 2,595{ }^{14} \mathrm{C}$ yrs BP (AA95057) and 46,100 \pm $2,595{ }^{14} \mathrm{C}$ yrs BP (AA99936); the sample from Aringo yielded an infinite age of $>49,900{ }^{14} \mathrm{C}$ yrs BP (AA95785). As these age estimates are at or very close to the limits of the AMS radiocarbon method, they are best considered minimum ages given the problem of even trace amounts of recent contaminates yielding spurious results. In addition, a freshwater stromatolite deposit overlying the Miocene bedrock at Aringo is associated with a U-series date of $455 \pm 45 \mathrm{ka}$, but this provides only an extreme maximum age for the overlying Pleistocene sediments discussed here 
(Beverly et al., in press). These age estimates are consistent with the tephra correlations to the Late Pleistocene sediments on Rusinga and Mfangano. AMS radiocarbon age estimates on gastropods that burrowed into the Rusinga and Mfangano sediments after deposition provide a minimum age estimate of $\sim 45 \mathrm{ka}$. Maximum age estimates are provided by the composition of the tephras, which suggests they derive from East African rift system volcanoes that began erupting early in the Late Pleistocene 100 ka (Tryon et al., 2010, 2012, Blegen et al., in review), and U-series age estimates on a tufa deposit at the base of the Pleistocene section at Nyamita on Rusinga Island (below the Nyamita Tuff in Fig. 4), which range from $94.0 \pm 3.3 \mathrm{ka}$ to $111.4 \pm 4.2 \mathrm{ka}$ (Beverly et al., in press). Optically stimulated luminescence (OSL) ages from channel deposits immediately above and below the Nyamita Tuff at Nyamita are $47 \pm 5 \mathrm{ka}$ and $51 \pm 5 \mathrm{ka}$ (Blegen et al., in review). Taken together, the current evidence suggests that the Pleistocene sequence at Karungu dates from $\sim 45$ to $94 \mathrm{ka}$.

\section{Pleistocene archaeology}

Artifacts were collected from all localities spanning the Pleistocene sequence at Karungu (Fig. 4). The recovered artifact sample is summarized in Table 1. Artifact densities from surface crawls and the Aringo 3 excavation range from $0.36-43.2$ artifacts $/ \mathrm{m}^{2}$, comparable to Late Pleistocene MSA assemblages from nearby Rusinga Island and other open-air sites made by foragers in general (see Garrett et al., in press). Although the sample size $(n=401)$ is too small to diagnose specific industrial affiliation, the recovered artifacts are consistent with a MSA attribution, particularly the presence of points, blades, and preferential and recurrent Levallois 
flakes and cores (Fig. 5), which occur with discoidal, casual, and multiplatform bipolar cores (definitions follow Isaac, 1977; Mehlman, 1989; Boëda, 1994, 1995) and rare retouched tools including scrapers. The occurrence of such diagnostic MSA artifacts (Table 1) spans the entire Pleistocene sequence at Karungu, ranging from the base of the sequence in the Aringo 3 excavation to the top of the sequence at Obware and portions of Kisaaka (Fig. 4). A very large Levallois core (151 mm maximum dimension) from Aringo resembles those from Acheulean contexts in the Kapthurin formation, Kenya (Tryon et al., 2005), although the only diagnostic ESA implement includes a single handaxe recovered from a modern alluvial deposit atop the Miocene bedrock at Kisaaka. Like many of the ESA artifacts collected by Owen $(1938,1939)$ and housed at the NMK, it is heavily rolled and weathered, unlike the MSA material we observed and collected from Karungu. These ESA artifacts likely derive from older sediments since eroded away. Unlike Owen (1937), who noted "Kenyan Aurignacian" artifacts and pottery associated with multiple presumably Holocene burials, we found no clear evidence for LSA occupation at Ngira or elsewhere in the Pleistocene exposures at Karungu (i.e., no backed pieces of any kind). The absence of LSA implements may be the result of Owen's (1937) extensive excavation of $\sim 400 \mathrm{~m}^{2}$ compounded by recent erosion of the presumably Holocene deposits at Ngira (Fig. 2).

All MSA artifacts are made of a wide range of raw materials, including various lavas, quartz, quartzite, and chert, consistent with the area's location at the interface between carbonatite-nephelinite volcanic complexes and outcrops of crystalline basement rock (Le Bas, 1977). The geochemical composition of the obsidian artifacts recovered from the Aringo 3 excavation (LVP2014-31) and from the surface at Kisaaka (LVP-2014-32) are reported in Table 2. To illustrate the relationships of 
these specimens to the 77 Kenyan obsidian sources documented by Brown et al. (2013), Figure 6 presents a Principal Components Analysis of major elements and oxides. The first three principal components account for the majority (>98\%) of variation in obsidian geochemistry $($ Principal Component $(\mathrm{PC}) 1=83.6 \%, \mathrm{PC} 2=$ $13.1 \%, P C 3=1.9 \%)$. Examination of $P C 1$ vs $P C 2$ and $P C 1$ vs $P C 3$ show the Karungu specimens to be very similar in composition to sources from the OI Karia Group near Lake Naivasha (Broad Acres 1-2, Gorge Farm, Hell's Gate 1-2, Kibikoni $1-2$, Ol Karia, Ololbutot 1-2) as well as Akira in southern Kenya (20 km south of Lake Naivasha), all of which are $\sim 250 \mathrm{~km}$ east of Karungu.

\section{Vertebrate fauna}

The vertebrate remains from the Pleistocene deposits at Karungu belong almost exclusively to large mammals and microfauna (Fig. 7), with only rare remains of tortoise and other small unidentified reptiles. We observed no bones, teeth, or scutes belonging to Nile crocodile (Crocodylus niloticus), which is known throughout Lake Victoria and associated river systems today (Spawls et al., 2002) and is commonly found in the local Holocene (Robertshaw et al., 1983) and Miocene (Pickford, 1984; Lehman et al., 2014) records.

\section{Large mammals}

Fossil remains of large mammals are well preserved and abundant at Karungu (Table 3). The dominance of alcelaphine antelopes and equids $(70 \%$ of all large mammal specimens), including the extinct wildebeest Rusingoryx 
atopocranion, the extinct blesbok Damaliscus hypsodon, blue wildebeest (Connochaetes taurinus), hartebeest (Alcelaphus buselaphus), plains zebra (Equus quagga), and Grevy's zebra (Equus grevyi), indicates the prevalence of open grassland vegetation. Among the bovids, alcelaphines and antilopines account for $76 \%$ of identified specimens, an abundance paralleled only in contemporary ecosystems characterized by arid to semi-arid grassland environments (e.g., Vrba, 1980; Alemseged, 2003). The dominant bovids, R. atopocranion and D. hypsodon, are characterized by exceptional hypsodonty (Faith et al., 2011, 2012), a probable adaptation to consuming grasses in dry and gritty environments (Marean, 1992; Damuth and Janis, 2011). Drier conditions than present are further supported by the recovery of arid-adapted Grevy's zebra and oryx (Oryx beisa; Kingdon, 1982; Faith et al., 2013), although the presence of blue wildebeest suggests at least seasonal availability of moist grasses (Skinner and Chimimba, 2005). Rare fossils of bushbuck (Tragelaphus scriptus) and black rhinoceros (Diceros bicornis) suggest a small component of closed habitats (e.g., shrubland), while the presence of hippopotamus (Hippopotamus amphibius) indicates at least some free-standing water.

The Karungu faunal assemblage includes a large number of extinct taxa compared to Late Pleistocene faunal assemblages from elsewhere in Africa (Faith, 2014). In addition to $R$. atopocranion and $D$. hypsodon, extinct bovids include the long-horn buffalo (Syncerus antiquus), giant wildebeest (Megalotragus sp.), and a large-bodied and very hypsodont impala (Aepyceros sp. nov.; Faith et al., 2014), all of which are characterised by specialised grassland adaptations (e.g., large body size or extreme hypsodonty; Faith, 2014). In addition to these extinct taxa, several of the extant ungulate species at Karungu occur well outside ( 250 to $500 \mathrm{~km})$ their historic geographic ranges (Fig. 8), including Grevy's zebra, white rhinoceros 
(Ceratotherium simum), oryx, and southern reedbuck (Redunca arundinum). These species are historically known from regions north, south, and east of Lake Victoria (Fig. 8).

Microfauna

Preservation of microfauna at Karungu is exceptional (Fig. 7), in contrast to many open-air Pleistocene sites in East Africa. A large rodent sample (NISP $=78)$ was recovered from Kisaaka, with only a few specimens recovered elsewhere (Table 3). Two taxa are present: East African mole rat (Tachyoryctes splendens) and vlei rat (Otomys sp.). The dominance of these relatively large rodent taxa is likely a reflection of size-based sampling bias. The East African mole rat occurs in a diverse range of habitats, ranging from tropical moist forest and open woodland to grassland. Extant representatives of Tachyoryctes are typically found in regions with rainfall in excess of $500 \mathrm{~mm} / \mathrm{yr}$, avoiding arid savannas and preferring well-drained soils suitable for digging complex and extensive burrows (Kingdon, 1982; Nowak, 1999). The presence of Otomys is consistent with the grassland environment implied by the large mammals. In modern systems, species of Otomys prefer moist grasslands, and in the dry season are frequently found in marshy areas around the edges of rivers or swamps (Smithers, 1971).

\section{Isotope paleoecology}

$\delta^{13} \mathrm{C}$ values of 20 tooth enamel samples from at least seven bovid species and 17 samples from East African mole rat are presented in Table 4 and Figure 9. 
Dietary categories for bovid taxa follow Cerling et al. (2003) and include the designations hypergrazer $\left(>95 \% \mathrm{C}_{4}\right)$, grazer $\left(70-95 \% \mathrm{C}_{4}\right)$, or mixed feeder $\left(>30 \% \mathrm{C}_{4}\right.$ and $>30 \% \mathrm{C}_{3}$ ). These designations reflect the degree of $\mathrm{C}_{4}$ grass consumption in lowland tropical environments in many parts of East Africa; $\mathrm{C}_{4}$ grasses are only outcompeted by $\mathrm{C}_{3}$ grasses under certain climatological and environmental conditions, such as increased atmospheric $\mathrm{pCO}_{2}$, high elevation (typically $>2,000 \mathrm{~m}$ in East Africa), changes in rainfall seasonality, and decreased fire prevalence and grazing pressure (Tieszen et al., 1979; Sage and Monson, 1999).

Isotope data from the Karungu bovids and rodents indicate diets dominated by $\mathrm{C}_{4}$ biomass. We caution that carbon isotope values from fossil tooth enamel cannot distinguish between the dominance of $\mathrm{C}_{4}$ grasses on the landscape from dietary preference for $\mathrm{C}_{4}$ grasses among a mixed $\mathrm{C}_{3} / \mathrm{C}_{4}$ ground vegetation layer with $\mathrm{C}_{4}$ grasses and $\mathrm{C}_{3}$ forbs, herbs, and shrubs. Additionally, minor isotopic variation among $\mathrm{C}_{4}$ plants is associated with different photosynthetic sub-pathways, with mesic-adapted $\mathrm{C}_{4}$ grasses slightly more enriched in $\delta^{13} \mathrm{C}$ than xeric-adapted $\mathrm{C}_{4}$ grasses (Cerling et al., 2003). Therefore, in addition to the potential for minor addition of $\mathrm{C}_{3}$ foods to the diet, the consumption of varying types of $\mathrm{C}_{4}$ grasses may explain some degree of variation seen within grazing taxa. Overall, these data agree well with isotope measurements of bovids from modern East African environments (Cerling et al., 2003), as well as with the contemporaneous fauna from nearby Rusinga and Mfangano Islands (Garrett et al., in press), and indicate that both large and small herbivores were associated with a landscape in which $\mathrm{C}_{4}$ grasses were abundant.

\section{Paleoenvironmental summary}


The Late Pleistocene sediments of Karungu provide a rare opportunity to reconstruct the environmental context of landscapes occupied by MSA humans in East Africa. The paleosols at Karungu (Fig. 4) indicate highly seasonal precipitation with prolonged periods of dry conditions that allowed the soils to become desiccated; the development of the basal paleosol indicates that these conditions persisted for at least hundreds to a few thousand years (Mermut et al., 1996; Buol et al., 2003; Southard et al., 2011). As is also the case of the Late Pleistocene sites at nearby Rusinga and Mfangano Islands (Tryon et al., 2010, 2012, 2014), the mammalian fauna of Karungu indicate a paleoenvironment dominated by grassland vegetation, distinct from the evergreen bushlands, woodlands, and forests found in the region today. The stable carbon isotopic signature of rodents and bovids clearly indicate that these were $\mathrm{C}_{4}$ grasslands, at both local scales $\left(<1 \mathrm{~km}^{2}\right.$ for rodents) and larger scales (10s to 100 s of $\mathrm{km}^{2}$ ) commensurate with landscapes exploited by mobile populations of human foragers. The lack of bovids with $C_{3}$-dominated or mixed $C_{3} / C_{4}$ diets and the rarity of ungulate species with extant relatives that are browsers $(10 \%$ of NISP) suggests only a limited vegetation component of shrubs or trees.

Likely explanations for the increased presence of $\mathrm{C}_{4}$ grasslands in the Lake Victoria region relative to the present include reduced atmospheric $\mathrm{CO}_{2}$ concentrations, which favors $\mathrm{C}_{4}$ vegetation (Tieszen et al., 1979; Ehleringer et al., 1997), as well as a reduction in mean annual or wet-season precipitation, which are associated with decreased woody cover in African environments (Sankaran et al., 2005; Good and Caylor, 2011). Except during the Last Interglacial, Late Pleistocene atmospheric $\mathrm{CO}_{2}$ concentrations were lower than the Holocene (Petit et al., 1999) and several lines of evidence indicate drier paleoenvironments than the present. 
Crocodile remains are commonly found in Holocene LSA middens from the Lake Victoria region (Robertshaw et al., 1983) and they are ubiquitous at other MiocenePleistocene fossil localities in East Africa (e.g., Leakey, 1971; Tchernov, 1986; Storrs, 2003), including the Miocene of Karungu (Pickford, 1984; Lehman et al., 2014); their absence from the Karungu Pleistocene fossil assemblage attests to the ephemeral nature of fluvial systems responsible for depositing some of the Pleistocene sediments and/or to a greater distance to the shores of Lake Victoria compared to the Holocene. The presence of hippopotamus indicates at least some freestanding water and poses a puzzling contradiction, but their reliance on terrestrial forage may have allowed them to persist in very small springs similar to those documented on Rusinga Island (Tryon et al., 2012; Beverly et al., in press), whereas crocodiles rely heavily on aquatic prey (Corbet, 1960) and may have required larger water sources to support viable populations. Further evidence for drier conditions is provided by the presence of oryx and Grevy's zebra, which are adapted to arid to semi-arid environments and imply lower precipitation than at present (Marean, 1992; Faith et al., 2013). Last, the dominance of extinct bovid species characterized by exceptional hypsodonty, a probable adaptation to feeding in open and dry environments (Damuth and Janis, 2011), including D. hypsodon and R. atopocranion, is also consistent with reduced precipitation (Eronen et al., 2010).

The decrease in precipitation compared to the present implied by the Karungu evidence is likely to translate to a decline in the size and level of Lake Victoria, which is highly sensitive to local precipitation (Broeker et al., 1998; Milly, 1999). This is consistent with the implications of the fossil ungulates from contemporaneous deposits on nearby Mfangano Island (Tryon et al., 2014; Blegen et al., in review). Today Mfangano Island encompasses a mere $64 \mathrm{~km}^{2}$ of landmass, much of which is 
dominated by the steep topography of Mount Kwitutu, and is located $10 \mathrm{~km}$ from the Kenyan mainland and separated by a channel 25 meters in depth. As is the case of Karungu, its Late Pleistocene fossil assemblage is dominated by gregarious grassland ungulates (Tryon et al., 2012), some of which (e.g., wildebeest) are known to migrate long distances in response to seasonal resource availability. It is unlikely that migratory species would establish insular populations where such migrations are not possible, suggesting a likely connection to the mainland. This is further supported by the small size of Mfangano Island, which is insufficient to support viable populations of large gregarious game (Tryon et al., 2014). These lines of evidence imply a connection to the mainland, which requires a $\geq 25$ meter reduction in lake level (Tryon et al., 2014). Hydrological models (Broecker et al., 1998; Milly, 1999) suggest that the decrease in rainfall input needed to effect such change would have set in motion a series of feedback mechanisms translating to a dramatically reduced-if not desiccated_Lake Victoria (Tryon et al., 2014). While further chronological control is needed for the Mfangano Island fauna and for the age and duration of Pleistocene desiccations of Lake Victoria, it is intriguing that Stager and Johnson (2008) estimate a Late Pleistocene age of $~ 80$ ka (based on an extrapolation of sedimentation rates) for one of the desiccation surfaces documented in seismic surveys.

\section{Late Pleistocene dispersals}

Consistent with predictions from vegetation models (Cowling et al., 2008) and phylogeography (Lorenzen et al., 2012), the probable reduction of Lake Victoria and dominance of semi-arid $\mathrm{C}_{4}$ grasslands is associated with the convergence of 
historically allopatric grassland ungulates at Karungu (Fig. 8), a pattern also seen on nearby Rusinga Island (Tryon et al., 2010, 2012; Faith et al., 2013, in press). The combination of genetic, fossil, and paleoenvironmental evidence is consistent with the hypothesis that vegetation change mediated the expansion and fragmentation of species ranges across equatorial East Africa during the Pleistocene. However, whether or not these changes influenced the dispersal history of Late Pleistocene humans remains uncertain. Genetic evidence demonstrates that north-south human dispersals occurred across East Africa during the Late Pleistocene (Rito et al., 2013), but it is unclear whether these dispersals were influenced by the opening and closing of an equatorial dispersal barrier, as appears to be the case for the ungulates (Lorenzen et al., 2012; Fig. 8). Although few MSA sites are associated with detailed paleoenvironmental records, the occasional phases of vicariance caused by such a barrier (i.e., fragmentation of populations north and south of the equator) could contribute to the gradual accumulation of novel behavioral repertoires (Eerkens and Lipo, 2005). These should be reflected archaeologically by distinct technological signatures north and south of the barrier, reflecting behavioral divergence during phases of limited dispersal.

To test the hypothesis of an equatorial dispersal barrier, we examine variability in artifact assemblage composition across East African Late Pleistocene MSA sites. These are reported in Table 5, which summarizes variation in broad artifact classes across 30 assemblages from 15 of the better reported sites in the region. These include those assemblages designated Late MSA by Tryon and Faith (2013), supplemented by additional records from Shelter 7 at Laas Geel in Somalia (Gutherz et al., 2014), Goda Buticha in Ethiopia (Pleurdeau et al., 2014), and Magubike in Tanzania (Willoughby, 2012). We exclude Middle Pleistocene MSA 
sites from consideration given the evidence for some temporal shifts in assemblage composition between these and younger sites (Tryon and Faith, 2013). The artifact categories used here are broad (e.g., bipolar core, blade) to minimize problems introduced by variable artifact typologies used among different researchers (e.g., Vermeersch, 2001). To quantify the variability in assemblage composition, we conduct Principal Coordinates Analysis (PCoA) on a similarity matrix obtained using the Dice coefficient for presence/absence data (Fig. 10) in the Paleontological Statistics Package (Hammer et al., 2001). For a given pair of assemblages, the Dice coefficient is calculated $2 j /(a+b)$, where $j$ is the number of artifact classes that cooccur at assemblages $A$ and $B, a$ is the number of artifact classes at site $A$, and $b$ is the number of artifact classes at site B. The PCoA arranges assemblages in multidimensional space such that similar assemblages cluster together and dissimilar assemblages are grouped apart. For the purposes of this analysis, artifact classes indicated with a question mark (uncertain presence) in Table 5 are considered absent.

The PCoA reveals strong latitudinal patterning in assemblage composition when Axis 1 (23.1\% of the variance) is plotted against Axis 3 (10.1\% of the variance; Fig. 10). With a few exceptions, which include Karungu, Rusinga, and Prolonged Drift, those sites located at or south of the equator cluster apart from those sites located further north ( $>5^{\circ}$ latitude). This is confirmed by significant differences in average Axis $1(t=2.197, p=0.036)$ and Axis 3 scores $(t=3.390, p=0.002)$ between the northern and southern sites. Fisher's exact tests comparing the frequencies of assemblages with or without a given artifact type between northern and southern sites indicates that these differences are driven in part by the more frequent presence of bipolar cores $(p=0.026)$ and anvils $(p=0.003)$ and the rarity of 
Levallois points or point cores $(p=0.011)$ and large bifaces $(p=0.012)$ in the southern assemblages.

Our analysis indicates north-south geographic patterning in the composition of East African Late Pleistocene MSA artifact assemblages. While this is consistent with the hypothesis of an equatorial dispersal barrier, other possible explanatory mechanisms include environmental gradients, site type (open-air versus cave), and chronology. Paleoenvironmental evidence is largely lacking for many of these assemblages, but modern precipitation, which plays a key role in determining African vegetation structure (Sankaran et al., 2005; Good and Caylor, 2011), broadly varies along a longitudinal gradient (increasing to the west) in the region examined here (Hijmans et al., 2005). To the extent that contemporary precipitation gradients can be extended into the past, this suggests that environment is an unlikely explanation for the variation observed here. The north-south geographic patterning evident in Figure 10 could potentially reflect differential representation of various site types. However, this is not the case here, as the northern and southern clusters include comparable proportions of assemblages from caves/rockshelters and open-air sites (Fisher's exact test: $p=0.284$ ). Although chronological control is generally poor, we note the presence of relatively early Late Pleistocene MSA assemblages (> $60 \mathrm{ka}$ ) in both the south (e.g., Mumba Bed Vl; Gliganic et al., 2012) and north (e.g., Ardu Beds; Yellen et al., 2005) and relatively young Late Pleistocene MSA assemblages ( 40 to $50 \mathrm{ka}$ ) in both the south (e.g, Mumba Beds III and IV; Gliganic et al., 2012) and north (e.g., Mochena Borago; Brandt et al., 2012). This suggests that the geographic differences observed in Figure 10 cannot be readily attributed to chronological variation. In the absence of apparent differences related to environment, site type, or chronology, the geographic patterns documented here are potentially indicative of regionally-distinct 
technological patterns. Such regional variation is consistent with behavioral divergence during periodic phases of allopatry, for which the equatorial dispersal barrier is a plausible mechanism.

While the previous analyses reveal geographic variation consistent with an equatorial dispersal barrier, it is not clear whether human dispersals were linked to phases of grassland expansion across equatorial East Africa. As an initial exploration of this scenario, we return to grassland-associated MSA assemblages from Karungu and nearby Rusinga Island, two of the few assemblages associated with detailed paleoenvironmental records. These two sites are regional outliers in terms of artifact assemblage composition, showing affinities with assemblages from the north (Fig. 10). To quantitatively confirm this pattern we calculated the Dice coefficient between Karungu and Rusinga and all other assemblages; Karungu and Rusinga show greater similarity with those from the north (average $=0.760$ ) than with those from the south (average $=0.670 ; t=3.700, p<0.001$ ). Although additional archaeological and environmental data are much needed from throughout East Africa, this observation is consistent with a possible north-to-south dispersal of archaeological (and thus hominin behavioral) patterns-and perhaps human dispersals_during a paleoenvironmental phase dominated by grasslands.

\section{Discussion}

Models of Quaternary vegetation change (Cowling et al., 2008) coupled with insights from the genetic structure of contemporary vertebrates (Dehgani et al., 2008; Miller et al., 2011; Lorenzen et al., 2012) suggest that the opening and closing of the equatorial East African forest belt during the Quaternary may have played a 
key role in mediating north-south dispersals of fauna and perhaps early modern humans. The paleoenvironmental and paleontological evidence from Karungu is consistent with these predictions. Karungu's Late Pleistocene sedimentary archive indicates a semi-arid environment characterized by highly seasonal precipitation and the dominance of $\mathrm{C}_{4}$ grasslands, likely accompanied by a substantial reduction in the size of Lake Victoria. In agreement with hypotheses derived from genetic observations (Lorenzen et al., 2012), these conditions are associated with the convergence of ungulate species whose geographic ranges are today-and presumably during previous climate phases with high moisture availabilityseparated by the equatorial East African forest belt (Fig. 8). A complementary pattern is seen in Kibish Formation of southern Ethiopia, where sediments deposited during humid phases from the late Middle Pleistocene through the Holocene document a northward expansion of mesic-adapted ungulates (Rowan et al., 2015). These records provide intriguing support for the argument that vegetation change across equatorial East Africa played a decisive role in species dispersals, a hypothesis to be tested with additional data from a broader time frame and wider geographic area.

Our analysis of the Late Pleistocene MSA record from East Africa reveals previously unrecognized north-south variation in assemblage composition (Fig. 10), paralleling the geographic patterns observed in the genetic records of ungulates (Lorenzen et al., 2012) and other vertebrates (Dehgani et al., 2008; Miller et al., 2011). We interpret these differences, reflecting to some extent the variable occurrence of bipolar cores, anvils, large bifaces, and Levallois points or point cores (Table 5), as potentially indicating the development of regionally distinct behavioral patterns during past episodes of population fragmentation, for which the equatorial 
dispersal barrier is a probable driver. In agreement with Cowling et al. (2008), this implies that the potential for north-south human dispersals across East Africa would have been maximized during climate phases that promoted an expansion of grassland cover.

The grassland-associated MSA assemblages from Karungu and nearby Rusinga Island are characterized by a combination of artifact types that is more typical of sites found further north of the equator. This may reflect the southward dispersal of northern behavioral repertoires during a grassy phase that facilitated dispersals, including those dispersals of northern ungulates such as Grevy's zebra and white rhinoceros (Fig. 8). This complements our previous observations that the presence of small bifacial points at Rusinga Island (Tryon et al., 2010, 2012) and now reported from Karungu (Fig. 5) may reflect the dispersal of a grassland associated technology, as these are similar to those found throughout Rift Valley sites in East Africa (Tryon et al., 2012; Tryon and Faith, 2013; Faith et al., in press). Such connections to the Rift Valley are further supported by the presence of exotic obsidian flakes from Aringo and Kisaaka, the geochemistry of which are very similar to well-documented sources south of Lake Naivasha (Brown et al., 2013). While extensive mapping of the volcanics surrounding Lake Victoria has yet to document any local obsidian sources (Le Bas, 1977), it is highly unlikely that any undocumented local sources would be geochemically identical to the Naivasha obsidians. The most parsimonious explanation is that the obsidian artifacts from Karungu are derived from the Lake Naivasha region $250 \mathrm{~km}$ east. This places them at the upper range of documented long-distance raw material transport in the MSA and likely indicates exchange and interaction between social groups, as such a distance potentially exceeds that of deliberate collecting forays by a single group 
(see review in McBrearty and Brooks, 2000). While this evidence for grasslandmediated human dispersals is tentative and will require a greater number of East African MSA sites with detailed paleoenvironmental records to test in detail, the structure of the MSA record is consistent with the hypothesis that vegetation change across equatorial East Africa mediated the dispersal and fragmentation of Pleistocene human populations.

\section{Faunal turnover}

Previous research on late Quaternary fossil assemblages from East Africa indicated that—with a few minor exceptions (Marean and Gifford-Gonzalez, 1991; Marean, 1992)_an essentially modern faunal community was in place by $\sim 400 \mathrm{ka}$ (Potts et al., 1988; Potts and Deino, 1995). However, the emerging evidence from the Lake Victoria Basin reveals the long-term survival of archaic lineages thought to have disappeared $>500 \mathrm{ka}$, including Kolpochoerus, together with the many extinct bovids characterized by large body mass or exceptional hypsodonty, including $S$. antiquus, Megalotragus, D. hypsodon, R. atopocranion, and Aepyceros sp. nov. (Faith et al., 2011, 2012, 2014; Faith, 2014). Of these, only S. antiquus and D. hypsodon are known from other Late Pleistocene faunal assemblages in East Africa (Marean and Gifford-Gonzalez, 1991; Marean, 1992; Faith et al., 2012; Rowan et al., 2015). The presence and dominance of numerous extinct forms at Karungu and nearby Rusinga and Mfangano Islands may be indicative of an endemic Pleistocene fauna or a long-term refugium in the Lake Victoria Basin. However, the relevant faunal collections from elsewhere are relatively small (Assefa et al., 2008; Eren et al., 2014; Rowan et al., 2015) or derived from highly fragmented archaeological 
contexts (Mehlman, 1989; Marean, 1992; Assefa, 2006; Prendergast et al., 2007), potentially masking faunal diversity and raising the possibility that extinct lineages were geographically widespread but have yet to be identified. The mesic-adapted faunal community from the Kibish Formation includes only a few specimens of $D$. hypsodon and may indicate that the dominance of extinct forms observed in the Lake Victoria region is specific to relatively arid environments (Rowan et al., 2015). Whatever the explanation, the evidence from the Lake Victoria Basin leaves little doubt that patterns of late Quaternary faunal turnover and paleoecological change in East Africa are far more complex than previously imagined.

\section{Conclusions}

The opening and closing of biogeographic barriers are thought to have played an important role in mediating human dispersals during the Pleistocene (Vaks et al., 2007; Cowling et al., 2008; Carto et al., 2009; Compton, 2011; Faith et al., in press), although precise details in East Africa are scarce due to a lack of archaeological data associated with paleoenvironmental records. With this in mind, we provide the first detailed description of the fossil- and artifact-bearing Pleistocene deposits from Karungu, an area that has been intermittently explored by paleoanthropologists for over 100 years. Lithic artifacts recovered from surface collections and from controlled excavation are typologically MSA. The presence of an associated and well-preserved paleontological assemblage is rare for the East African MSA and provides crucial paleoenvironmental insight. The combination of faunal, sedimentological, and geochemical evidence indicates that the Karungu MSA is associated with a $\mathrm{C}_{4}$ grassland-dominated environment and a reduction in 
precipitation, which probably contributed to a substantial reduction in the size of Lake Victoria. Consistent with genetic evidence (Lorenzen et al., 2012), such conditions potentially facilitated the dispersal and convergence of grassland ungulates from various regions surrounding the Lake Victoria Basin. Together with our analysis of variation in the regional Late Pleistocene MSA record, there is intriguing evidence that vegetation change mediated the biogeographic histories of both humans and fauna across equatorial East Africa. Testing this hypothesis in further detail remains a priority for future research and will require continued exploration of the East African MSA.

\section{Acknowledgments}

Fieldwork at Karungu was conducted under research permits NCST/RCD/12B/012/31 issued to JTF, NCST/5/002/R/576 issued to CAT, NCST/RCD/12B/01/07 issued to DJP, and NCST/5/002/R/605 issued to EJB, and an exploration and excavation license issued by the National Museums of Kenya (NMK). We thank Sheila Nightingale for providing the artifact illustrations. Our fieldwork is made possible through the support of the NMK and with financial support from the National Geographic Society Committee for Research and Exploration (9284-13 and 8762-10), the National Science Foundation (BCS-1013199 and BCS 1013108), the Leakey Foundation, the Geological Society of America, the Society for Sedimentary Geology, the University of Queensland, Baylor University, the Baylor University Department of Geology Dixon Fund, New York University, the American School for Prehistoric Research, and Harvard University. We thank Sarah Elton, the 
Faith et al. 34

Associate Editor, and the anonymous reviewers for their helpful suggestions on a previous version of this manuscript.

\section{Supplementary data}

Geochemical data documenting tephra correlations between sites at Karungu and between Karungu and Rusinga Island are available in the online supplementary data. 


\section{References}

Adams, W.M., 1996. Lakes. In: Adams, W.M., Goudie, A.S., Orme, A.R. (Eds.), The Physical Geography of Africa. Oxford University Press, Oxford, pp. 122-133.

Alemseged, Z., 2003. An integrated approach to taphonomy and faunal change in the Shungura Formation (Ethiopia) and its implications for hominid evolution. J. Hum. Evol. 44, 451-478.

Allsopp, R., Baldry, D.A.T., 1972. A general description of the Lambwe Valley area of South Nyanza District, Kenya. B. World Health Organ. 47, 691-697.

Ambrose, S.H., Lorenz, K.G., 1990. Social and ecological models for the Middle Stone Age in southern Africa. In: Mellars, P. (Ed.), The emergence of modern humans: an archaeological perspective. Edinburgh University Press, Edinburgh, pp. 3-33.

Andrews, C.W., 1911. On a new species of Dinotherium (Dinotherium hobleyi) from British East Africa. Proc. Zool. Soc. Lond. 81, 943-945.

Andrews, C.W., 1914. On the Lower Miocene vertebrates from British East Africa, collected by Dr. Felix Oswald. Q. J. Geol. Soc. Lond. 70, 163-186.

Andrews, C.W., 1916. Note on a new baboon (Simopithecus oswaldi gen. et sp. nov.) from the (?) Pliocene of British East Africa. Annls. Mag. Nat. Hist. 18, 410-419

Andrews, P., 1981. A short history of Miocene field palaeontology in Western Kenya. J. Hum. Evol. 10, 3-9.

Assefa, Z., 2006. Faunal remains from Porc-Epic: paleoecological and zooarchaeological investigations from a Middle Stone Age site in southeastern Ethiopia. J. Hum. Evol. 51, 50-75. 
Assefa, Z., Yirga, S., Reed, K.E., 2008. The large-mammal fauna from the Kibish Formation. J. Hum. Evol. 55, 501-512.

Behrensmeyer, A.K., 2006. Climate change and human evolution. Science 311, 476-478.

Behrensmeyer, A.K., Potts, R., Plummer, T.W., Tauxe, L., Opdyke, N., Jorstad, T., 1995. The Pleistocene locality of Kanjera, Western Kenya: stratigraphy, chronology and paleoenvironments. J. Hum. Evol. 29, 247-274.

Beuning, K.R., Kelts, K., Russell, J., Wolfe, B.B., 2002. Reassessment of Lake Victoria-Upper Nile River paleohydrology from oxygen isotope records of lakesediment cellulose. Geology 30, 559-562.

Beverly, E.J., Driese, S.G., Peppe, D.J., Johnson, C.R., Michel, L.A., Faith, J.T., Tryon, C.A., Sharp, W., in press. Recurrent spring-fed rivers in a Middle to Late Pleistocene semi-arid grassland: implications for environments of early humans in the Lake Victoria Basin, Kenya. Sedimentology. doi: 10.1111/sed.12199.

Blegen, N., Tryon, C.A., Faith, J.T., Peppe, D.J., Beverly, E., Jacobs, Z., Li, B., in review. Distal tephras of the eastern Lake Victoria Basin, Equatorial East Africa: correlations, chronology, and a context for early modern humans. Quatern. Sci. Rev.

Blome, M.W., Cohen, A.S., Tryon, C.A., Brooks, A.S., Russell, J., 2012. The environmental context for the origins of modern human diversity: a synthesis of regional variability in African climate 150,000-30,000 years ago. J. Hum. Evol. $62,563-592$.

Boëda, E., 1994. Le concept Levallois: variabilité des méthodes. Centre National de la Recherche Scientifique, Paris. 
Boëda, E., 1995. Levallois: a volumetric construction, methods, a technique. In: Dibble, H.L., Bar-Yosef, O. (Eds.), The definition and interpretation of Levallois technology. Prehistory Press, Madison, WI, pp. 41-68.

Bootsma, H.A., Hecky, R.E., 2003. A comparative introduction to the biology and limnology of the African Great Lakes. J. Great Lakes Res. 29, 3-18.

Brandt., S.A., Fisher, E.C., Hildebrand, E.A., Vogelsang, R., Ambrose, S.H., Lesur, J., Wang, H., 2012. Early MIS3 occupation of Mochena Borago Rockshelter, southwest Ethiopian highlands: implications for Late Pleistocene archaeology, paleoenvironments and modern human dispersals. Quatern. Int. 274, 38-54.

Broecker, W.C., Peteet, D., Hajdas, I., Lin, J., 1998. Antiphasing between rainfall in Africa's Rift Valley and North America's Great Basin. Quatern. Res. 50, 12-20. Brown, F.H., McDougall, I., Fleagle, J.G., 2012. Correlation of the KHS Tuff of the Kibish Formation to volcanic ash layers at other sites, and the age of early Homo sapiens (Omo I and Omo II). J. Hum. Evol. 63, 577-585.

Brown, F.H., Nash, B.P., Fernandez, D.P., Merrick, H.V., Thomas, R.J., 2013. Geochemical composition of source obsidians from Kenya. J. Archaeol. Sci. 40, 3233-3251.

Buol, S.W., Southard, R.J., Graham, R.C., McDaniel, P.A., 2003. Vertisols: shrinking and swelling dark clay soils. In: Soil Genesis and Classification. WileyBlackwell, Oxford, pp. 385-395.

Campbell, M.C., Tishkoff, S.A., 2010. The evolution of human genetic and phenotypic variation in Africa. Curr. Biol. 20, R166-R173.

Carto, S.L., Weaver, A.J., Hetherington, R., Lam, Y., Wiebe, E.C., 2009. Out of Africa and into an ice age: on the role of global climate change in the late 
Pleistocene migration of early modern humans out of Africa. J. Hum. Evol. 56, $139-151$.

Cerling, T.E., Harris, J.M., 1999. Carbon isotope fractionation between diet and bioapatite in ungulate mammals and implications for ecological and paleoecological studies. Oecologia 120, 347-363.

Cerling, T.E., Harris, J.M., Passey, B.H., 2003. Diets of east African bovidae based on stable isotope analysis. J. Mammal. 84, 456-470.

Cerling, T.E., Levin, N.E., Passey, B.H., 2011. Stable isotope ecology in the OmoTurkana Basin. Evol. Anthropol. 20, 228-237.

Codron, J., Duffy, K.J., Avenant, N.L., Sponheimer, M., Leichliter, J., Paine, O., Sandberg, P., Codron, D., in press. Stable isotope evidence for trophic niche partitioning in a South African savanna rodent community. Curr. Zool.

Compton, J.S., 2011. Pleistocene sea-level fluctuations and human evolution on the southern coastal plain of South Africa. Quatern. Sc. Rev. 30, 506-527.

Corbet, P.S., 1960. The food of a sample of crocodiles (Crocodilus niloticus L.) from Lake Victoria. Proc. Zool. Soc. Lond. 133, 561-572.

Cowling, S.A., Cox, P.M., Jones, C.D., MAslin, M.A., Peros, M., Spall, S.A., 2008. Simulated glacial and interglacial vegetation across Africa: implications for species phylogenies and trans-African migration of plants and animals. Glob. Change Biol. 14, 827-840.

Creveceour, I., Rougier, H., Grine, F., Froment, A., 2009. Modern human cranial diversity in the late Pleistocene of Africa and Eurasia: evidence from Nazlet Khater, Pestera cu Oase, and Hofmeyr. Am. J. Phys. Anthropol. 140, 347-358. 
Damuth, J., Janis, C.M., 2011. On the relationship between hypsodonty and feeding ecology in ungulate mammals, and its utility in palaeoecology. Biol. Rev. 86, 733-758.

Dehghani, R., Wanntorp, L., Pagani, P., Källersjö, M., Werdelin, L., Veron, G., 2008.

Phylogeography of the white-tailed mongoose (Herpestidae, Carnivora, Mammalia) based on partial sequences of the mtDNA control region. J. Zool. 276, 385-393.

Ditchfield, P., Hicks, J., Plummer, T., Bishop, L.C., Potts, R., 1999. Current research on the Late Pliocene and Pleistocene deposits north of Homa Mountain, southwestern Kenya. J. Hum. Evol. 36, 123-150.

Doornkamp, J.C., Temple, P.H., 1966. Surface, drainage and tectonic instability in part of southern uganda. Geogr. J. 132, 238-252.

Eerkens, J.W., Lipo, C.P., .2005. Cultural transmission, copying errors, and the generation of variation in material culture and the archaeological record. J. Anthropol. Archaeol. 24, 316-334.

Ehleringer, J.R., Cerling, T.E., Helliker, B.R., 1997. C 4 photosynthesis, atmospheric $\mathrm{CO}_{2}$, and climate. Oecologia 112, 285-299.

Eren, M.I., Durant, A.J., Prendergast, M., Mabulla, A.Z.P., 2014. Middle Stone Age archaeology at Olduvai Gorge, Tanzania. Quatern. Int. 322-323, 292-313.

Eriksson, A., Betti, L., Friend, A.D., Lycett, S.J., Singarayer, J.S., von CramonTaubadel, N., Valdes, P.J., Balloux, F., Manica, A., 2012. Late Pleistocene climate change and the global expansion of anatomically modern humans. Proc. Natl. Acad. Sci. USA 109, 16089-16094. 
Eronen, J.T., Puolamäki, K., Liu, L., Lintulaakso, K., Damuth, J., Janis, C., Fortelius, M., 2010. Precipitation and large herbivorous mammals I: estimates from present-day communities. Evol. Ecol. Res. 12, 217-233.

Faith, J.T., 2014. Late Pleistocene and Holocene mammal extinctions on continental Africa. Earth-Sc. Rev. 128, 105-121.

Faith, J.T., Choiniere, J.N., Tryon, C.A., Peppe, D.J., Fox, D.L., 2011. Taxonomic status and paleoecology of Rusingoryx atopocranion (Mammalia, Artiodactyla), an extinct Pleistocene bovid from Rusinga Island, Kenya. Quatern. Res. 75, $697-707$.

Faith, J.T., Potts, R., Plummer, T.W., Bishop, L.C., Marean, C.W., Tryon, C.A., 2012. New perspectives on middle Pleistocene change in the large mammal faunas of East Africa: Damaliscus hypsodon sp. nov. (Mammalia, Artiodactyla) from Lainyamok, Kenya. Palaeogeogr. Palaeoclimatol. Palaeoecol. 361-362, 84-93.

Faith, J.T., Tryon, C.A., Peppe, D.J., Fox, D.L., 2013. The fossil history of Grévy's zebra (Equus grevyi) in equatorial East Africa. J. Biogeogr. 40, 359-369.

Faith, J.T., Tryon, C.A., Peppe, D.J., Beverly, E.J., Blegen, N., 2014. Biogeographic and evolutionary implications of an extinct late Pleistocene impala from the Lake Victoria Basin. J. Mammal. Evol. 21, 213-222.

Faith, J.T., Tryon, C.A., Peppe, D.J., in press. Environmental change, ungulate biogeography, and their implications for early human dispersals in equatorial East Africa. In: Jones, S.C., Stewart, B.A. (Eds.), Africa from MIS 6-2: Population Dynamics and Paleoenvironments. Springer.

Fullinger, U., Sonye, G., Killeen, G.F., Knols, B.G.L., Becker, N., 2004. The practical importance of permanent and semipermanent habitats for controlling aquatic 
stages of Anopheles gambiae sensu lato mosquitoes: operational observations from a rural town in western Kenya. Trop. Med. Int. Health 9, 1274-1289.

Garrett, N.D., Fox, D.L., McNulty, K.P., Tryon, C.A., Faith, J.T., Peppe, D.J., Van Plantinga, A., in press. Stable isotope paleoecology of late Pleistocene Middle Stone Age humans from equatorial East Africa, Lake Victoria basin, Kenya. J. Hum. Evol.

Gentry, A.W., 1970. The Bovidae (Mammalia) of the Fort Ternan fossil fauna. In: Leakey, L.S.B., Savage, R.J.G. (Eds.), Fossil Vertebrates of Africa 2. Academic Press, London, pp. 243-323.

Gliganic, L.A., Jacobs, Z., Roberts, R.G., Domínguez-Rodrigo, M., Mabulla, A.Z.P., 2012. New ages for Middle and Later Stone Age deposits at Mumba rockshelter, Tanzania: optically stimulated luminescence dating of quartz and feldspar grains. J. Hum. Evol. 62, 533-547.

Good, S., Caylor, K.K., 2011. Climatological determinants of woody cover in Africa. Proc. Natl. Acad. Sci. USA 108, 4902-4907.

Gunz, P., Bookstein, F.L., Mitteroecker, P., Stadlmayr, A., Seidler, H., Weber, G.W., 2009. Early modern human diversity suggests subdivided population structure and a complex out-of-Africa scenario. Proc. Natl. Acad. Sci. USA 106, 60946098.

Gutherz, X., Diaz, A., Ménard, C., Bon, F,. Douze, K., Léa, V., Lesur, J., Sordoillet, D., 2014. The Hargeisan revisited: lithic industries from shelter 7 of Laas Geel, Somaliland and the transition between the Middle and Late Stone Age in the Horn of Africa. Quatern. Int. 343, 69-84.

Hammer, Ø., Harper, D.A.T., Ryan, P.D., 2001. Paleontological statistics software package for education and data analysis. Palaeontol. Electron. 4. 
Harvati, K., Stringer, C., Grün, R., Aubert, M., Allsworth-Jones, P., Folorunso, C.A., 2013. The Later Stone Age calvaria from Iwo Eleru, Nigeria: morphology and chronology. PLos ONE 6, e24024.

Hijmans, R.J., Cameron, S.E., Parra, J.L., Jones, P.G., Jarvis, A., 2005. Very high resolution interpolated climate surfaces for global land areas. Int. J. Climatol. 25, 1965-1978.

Isaac, G.L., 1977. Olorgesailie: archaeological studies of a Middle Pleistocene lake basin in Kenya. University of Chicago Press, Chicago.

IUCN, 2013. IUCN Red List of Threatened Species. Version 2013.2 $<$ www.iucnredlist.org $>$.

Johnson, T.C., Scholz, C.A., Talbot, M.R., Kelts, K., Ricketts, R.D., Ngobi, G., Beuning, K.R., Ssemmanda, I., McGill, J.W., 1996. Late Pleistocene desiccation of Lake Victoria and the rapid evolution of cichlid fishes. Science 273, 1091-1093.

Johnson, T.C., Kelts, K., Odada, E., 2000. The Holocene history of Lake Victoria. Ambio 29, 2-11.

Kendall, R.L., 1969. An ecological history of the Lake Victoria basin. Ecol. Monogr. $39,121-176$.

Kent, P.E., 1942. The country round the Kavirondo Gulf of Victoria Nyanza. Geogr. J 100, 22-31.

Kimanzi, J.K., 2011. Mapping and modelling the population and habitat of roan antelope (Hippotragus equinus langheldi) in Ruma National Park, Kenya. Ph.D. Thesis, School of Biology, Newcastle University.

Kimura, Y., Jacobs, L.L., Cerling, T.E., Uno, K.T., Ferguson, K.M., Flynn, L.J., Ratnaik, R. 2013. Fossil Mice and Rats Show Isotopic Evidence of Niche 
Partitioning and Change in Dental Ecomorphology Related to Dietary Shift in Late Miocene of Pakistan. PLoS ONE 8, e69308.

Kingdon, J., 1982. East African Mammals. University of Chicago Press, Chicago.

Kingdon, J., 1990. Island Africa: The Evolution of Africa's Rare Animals and Plants. Princeton University Press, Princeton.

Koch, P.L., Tuross, N., Fogel, M., 1997. The effects of sample treatment and diagenesis on the isotopic integrity of carbonate in biogenic hydroxylapatite. J. Archaeol. Sci. 24, 417-430.

Le Bas, M.J., 1977. Carbonatite-nephelenite volcanism: an African case history. Wiley, London.

Le Gros Clark, W.E., Leakey, L.S.B., 1950. Diagnoses of East African Miocene hominoidea. Q. J. Geol. Soc. London 105, 260-262.

Leakey, L.S.B., 1974. By the Evidence: Memoirs 1932-1951. Harcourt Brace Jovanovich, New York.

Leakey, M.D., 1971. Olduvai Gorge, Volume 3, Excavations in Beds I and II, 1960_ 1963. Cambridge University Press, Cambridge.

Lee-Thorp, J.A., van Der Merwe, N.J., 1987. Carbon isotope analysis of fossil bone apatite. S. Afr. J. Sci. 83, 712-715.

Lehmann, T., Peppe, D.J., Driese, S.G., Jenkins, K., Sanders, W.J., McNulty, K.P., 2014. New fieldwork at Karungu (Early Miocene: Lake Victoria, Kenya): preliminary paleontological and geological results. Society of Vertebrate Paleontology Annual Meeting Program and Abstracts Volume, p. 168.

Linder, H.P., de Clerk, H.M., Born, J., Burgess, N., Fjeldså, J., Rahbek, C., 2012. The partitioning of Africa: statistically defined biogeographical regions in subSaharan Africa. J. Biogeogr. 39, 1189-1205. 
Lorenzen, E.D., Heller, R., Siegismund, H.R., 2012. Comparative phylogeography of African savannah ungulates. Mol. Ecol. 21, 3656-3670.

Marean, C.W., 1992. Implications of late Quaternary mammalian fauna from Lukenya Hill (south-central Kenya) for paleoenvironmental change and faunal extinctions. Quatern. Res. 37, 239-255.

Marean, C.W., 2010. Pinnacle Point Cave 13B (Western Cape Province, South Africa) in context: the Cape Floral kingdom, shellfish, and modern human origins. J. Hum. Evol. 59, 425-443.

Marean, C.W., Gifford-Gonzalez, D., 1991. Late Quaternary extinct ungulates of East Africa and palaeoenvironmental implications. Nature 350, 418-420.

McBrearty, S., Brooks, A.S., 2000. The revolution that wasn't: a new interpretation of the origin of modern human behavior. J. Hum. Evol. 39, 453-563.

McCall, G.S., 2007. Behavioral ecological models of lithic technological change during the later Middle Stone Age of South Africa. J. Archaeol. Sci. 34, 17381751.

McDougall, I., Brown, F.H., Fleagle, J., 2005. Stratigraphic placement and age of modern humans from Kibish, Ethiopia. Nature 433, 733-736.

McNulty, K.P., Maclatchy, L., Peppe, D.J., Nengo, I.O., Manthi, F.K., Miller, E.R., Stevens, N.J., Cote, S., Kingston, J., Lehmann, T., 2014. A regional approach to East African early Miocene paleobiology. Society of Vertebrate Paleontology Annual Meeting Program and Abstracts Volume, p. 185.

MehIman, M.J., 1989. Later Quaternary archaeological sequences in northern Tanzania, Ph.D. Thesis, University of Illinois, Urbana-Champaign. 
Mermut, A.R., Padmanabham, E., Eswaran, H., Dasog, G.S., 1996. Pedogenesis. In: Ahmad, N., Mermut, A. (Eds.), Vertisols and Technologies for their Management. Elsevier Science B.V., Netherlands, pp. 43-61.

Merrick, H.V., Brown, F.H., 1984. Obsidiean sources and pattern of source utilitzation in Kenya and nothern Tanzania. Afr. Archaeol. Rev. 2, 129-152.

Michel, L.A., Peppe, D.J., Lutz, J.A., Driese, S.G., Dunsworth, H.M., Harcourt-Smith, W.E.H., Horner, W.H., Lehmann, T., Nightingale, S., McNulty, K.P., 2014. Remnants of an ancient forest provide ecological context for Early Miocene fossil apes. Nature Communications 5, 3236.

Miller, J.M., Hallager, S., Monfort, S.L., Newby, J., Bishop, K., Tidmus, S.A., Black, P., Houston, B., Matthee, C.A., Fleischer, R.C., 2011. Phylogeographic analysis of nuclear and mtDNA supports subspecies designations in the ostrich (Struthio camelus). Conserv. Genet. 12, 423-431.

Milly, P.C.D., 1999. Comment on "Antiphasing between rainfall in Africa's Rift Valley and North America's Great Basin." Quatern. Res. 51, 104-107.

Newton, R.B., 1914. On some non-marine molluscan remains from the Victoria Nyanza region, associated with Miocene vertebrates. Q. J. Geol. Soc. Lond. 70, 187-198.

Nicholson, S.E., 1998. Historical fluctuations of Lake Victoria and other lakes in the northern rift valley of East Africa. In: Lehman, J.T. (Ed.), Environmental Change and Responses in East African Lakes. Kluwer Academic Publishers, Dordrecht, pp. 7-35.

Nowak, R.M., 1999. Walker's Mammals of the World. Sixth Edition. The Johns Hopkins University Press, Baltimore. 
Oswald, F., 1914. The Miocene beds of the Victoria Nyanza and the geology of the country between the lake and the Kisii Highlands. Q. J. Geol. Soc. Lond. 70, 128-159.

Owen, W.E., 1937. Draft of tentative preliminary report on the July 1937 investigations at Ng'ira Karungu. Unpublished manuscript housed in the archives of the Natural History Museum, London.

Owen, W.E., 1938. The Kombewa Culture, Kenya Colony. Man 38, 203-205.

Owen, W.E., 1939. An amateur field collector in Kavirondo. Part II. J. R. Afr. Soc. 38, $220-228$.

Peppe, D.J., McNulty, K.P., Cote, S.M., Harcourt-Smith, W.E.H., Dunsworth, H.M., Van Couvering, J.A., 2009. Stratigraphic interetation of the Kulu Formation (Early Miocene, Rusinga Island, Kenya) and its implications for primate evolution. J. Hum. Evol. 56, 447-461.

Petit, J.R., Jouzel, J., Raynaud, D., Barkov, N.I., Barnola, J.-M., Basile, I., Benders, M., Chappellaz, J., Davis, M., Delaygue, G., Delmotte, M., Kotlyakov, V.M., Legrand, M., Lipenkov, V.Y., Lorius, C., Pepin, L., Ritz, C., Saltzman, E., Stievenhard, M., 1999. Climate and atmospheric history of the past 420,000 years from the Vostok ice core, Antarctica. Nature 399, 429-436.

Pickford, M., 1984. Kenya Paleontology Gazeteer Volume 1: Western Kenya. National Museums of Kenya Department of Sites and Monuments Documentation, Nairobi.

Pickford, M., 1986. Cainozoic paleontological sites of Western Kenya. Münchner Geowissenschaftliche Abhandlungen 8, 1-151. 
Pickford, M., Thomas, H., 1984. An aberrant new bovid (Mammalia) in subrecent deposits from Rusinga Island, Kenya. Proc. K. Ned. Akad. Wetensc. B87, 441452.

Pleurdeau, D., Hovers, E., Assefa, Z., Asrat, A., Pearson, O., Bahain, J.-J., Lam, Y.M., 2014. Cultural change or continuity in the late MSA/Early LSA of southeastern Ethiopia? The site of Goda Buticha, Dire Dawa area. Quatern. Int. $343,117-135$.

Plummer, T.W., Ditchfield, P.W., Bishop, L.C., Kingston, J.D., Ferraro, J.V., Braun, D.R., Hertel, F., Potts, R., 2009. Oldest evidence of toolmaking hominins in a grassland-dominated ecosystem. PLoS ONE 4, e7199.

Potts, R., Deino, A., 1995. Mid-Pleistocene change in large mammal faunas of East Africa. Quatern. Res. 43, 106-113.

Potts, R., Shipman, P., Ingall, E., 1988. Taphonomy, paleoecology, and hominids of Lainyamok, Kenya. J. Hum. Evol. 17, 597-614.

Prendergast, M., Luque, L., Domínguez-Rodrigo, M., Diez-Martín, F., Mabulla, A.Z.P., Barba, R., 2007. New excavations at Mumba Rockshelter, Tanzania. J. Afr. Archaeol. 5, 217-243.

Rito, T., Richards, M.B., Fernandes, V., Alshamali, F., Cerny, V., Pereira, L., Soares, P., 2013. The first modern human dispersals across Africa. PLoS ONE 8 , e80031.

Robertshaw, P., Collett, D., Gifford, D., Mbae, N.B., 1983. Shell middens on the shores of Lake Victoria. Azania 18, 1-43.

Rookmaaker, K., Antoine, P.-O., 2013. New maps representing the historical and recent distribution of the African species of rhinoceros: Diceros bicornis, Ceratotherium simum, and Ceratotherium cottoni. Pachyderm 52, 91-96. 
Rowan, J., Faith, J.T., Gebru, Y., Fleagke, J.G., 2015. Taxonomy and paleoecology of fossil Bovidae (Mammalia, Artiodactyla) from the Kibish Formation, southern Ethiopia: implications for dietary change, biogeography, and the structure of living bovid faunsa of East Africa. Palaeogeogr. Paleoclimatol. Palaeoecol. 420, 210-222.

Sage, R.F., Monson, R.K., 1999. C4 Plant Biology. Academic Press, San Diego.

Sankaran, M., Hanan, N.P., Scholes, R.J., Ratnam, J., Augustine, D.J., Cade, B.S., Gignoux, J., Higgins, S.I., Le Roux, X., Ludwig, F., Ardo, J., Banyikwa, F., Bronn, A., Bucini, G., Caylor, K.K., Coughenour, M.B., Diouf, A., Ekaya, W., Feral, C.J., February, E.C., Frost, P.G., Hiernaux, P., Hrabar, H., Metzger, K.L., Prins, H.H., Ringrose, S., Sea, W., Tews, J., Worden, J., Zambatis, N., 2005. Determinants of woody cover in African savannas. Nature 438, 846-849.

Scholz, C.A., Johnson, T.C., Cohen, A.S., King, J.W., Peck, J.A., Overpeck, J.T., Talbot, M.R., Brown, E.T., Kalindekafe, L., Amoako, P.Y.O., Lyons, R.P., Shanahan, T.M., Castenada, I.S., Heil, C.W., Forman, S.L., McHargue, L.R., Beuning, K.R., Gomex, J., Pierson, J., 2007. East African megadroughts between 135 and 75 thousand years ago and bearing on early-modern human origins. Proc. Natl. Acad. Sci. USA 104, 16416-16421.

Scott, K.M., 1985. Allometric trends and locomotor adaptations in the Bovidae. Bull. Am. Mus. Nat. Hist. 179, 197-288.

Skinner, J.D., Chimimba, C.T., 2005. The Mammals of the Southern African Subregion. Cambridge University Press, Cambridge.

Smithers, R.H.N., 1971. The mammals of Botswana Museum Memoir No. 4. The Trustees of the National Museum of Rhodesia, Salisbury 4, 1-340. 
Soares, P., Alshamali, F., Pereira, J.B., Fernandes, V., Silva, N.M., Alfonso, C., Costa, M.D., Musilová, E., Macaulay, V., Richards, M.B., Černy, V., Pereira, L., 2012. The expansion of mtDNA haplogroup L3 within and out of Africa. Mol. Biol. Evol. 29, 915-927.

Southard, R.J., Driese, S., Nordt, L., 2011. Vertisols. In: Huang, P.M., Li, Y., Sumner, M.E., (Eds.), Handbook of Soil Science, $2^{\text {nd }}$ edition. CRC Press, Boca Raton, Florida, Section 33 pp. 82-97.

Spawls, S., Howell, K., Drewes, R.C., Ashe, J., 2002. A Field Guide to the Reptiles of East Africa. Academic Press, London.

Stager, J.C., Johnson, T.C., 2008. The late Pleistocene desiccation of Lake Victoria and the origin of its endemic biota. Hydrobiologia 596, 5-16.

Stager, J.C., Mayewski, P.A., Meeker, L.D., 2002. Cooling cycles, Heinrich event 1, and the desiccation of Lake Victoria. Palaeogeogr. Palaeoclimatol. Palaeoecol. 183, 169-178.

Stager, J.C., Ryves, D.B., Chase, B.M., Pausata, F.S.R., 2011. Catastrophic drought in the Afro-Asian monsoon region during Heinrich Event 1. Science 331, 1299 1302.

Storrs, G.W., 2003. Late Miocene-Early Pliocene crocodilian fauna of Lothagam, southwest Turkana Basin, Kenya. In: Leakey, M.G., Harris, J.M., (Eds.) Lothagam: the dawn of humanity in eastern Africa. Columbia University Press, New York, pp. 137-159.

Symes, C.T., Wilson, J.W., Woodborne, S.M., Shaikh, Z.S., Scantlebury, M., 2013. Resource partitioning of sympatric small mammals in an African forestgrassland vegetation mosaic. Austral. Ecol. 38, 721-729. 
Talbot, M.R., Laerdal, T., 2000. The Late Pleistocene-Holocene paleolimnology of Lake Victoria, East Africa, based upon elemental and isotopic analyses of sedimentary organic matter. J. Paelolimnol. 23, 141-164.

Talbot, M.R., Jensen, N.B., Laerdal, T., Filippi, M.L., 2006. Geochemical responses to a major transgression in giant African lakes. J. Paelolimnol. 35, 467-489.

Tchernov, E., 1986. Evolution of the crocodiles in East and North Africa. Cahiers de Paleontologie, Travaux de Paleontologies Est-Africaine, CNRS, pp. 1-65

Teaford, M.F., Beard, K.C., Leakey, R.E., Walker, A., 1988. New hominoid facial skeleton from the Early Miocene of Rusinga Island, Kenya, and its bearing on the relationship between Proconsul nyanzae and Proconsul africanus. J. Hum. Evol. 17, 461-477.

Temple, P.H., 1966. Evidence of changes in the level of Lake Victoria and their significance, Ph.D. Thesis, University of London.

Tieszen, L.L., Senyimba, M.M., Imbaba, S.K., Troughton, J.H., 1979. The distribution of $\mathrm{C}_{3}$ and $\mathrm{C}_{4}$ grasses and carbon isotope discrimination along an altitudinal and moisture gradient in Kenya. Oecologia 37, 337-350.

Tipple, B.J., Meyers, S.R., Pagani, M., 2010. The carbon isotope ratio of Cenozoic CO2: a compariative evaluation of available geochemical proxies. Paleoceanography 25, PA3202

Tryon, C.A., Faith, J.T., 2013. Variability in the Middle Stone Age of Eastern Africa. Curr. Anthropol. 54, S234-S254.

Tryon, C.A., McBrearty, S., Texier, P.-J., 2005. Levallois lithic technology from the Kapthurin Formation, Kenya: Acheuliean origin and Middle Stone Age diversity. Afr. Archaeol. Rev. 22, 199-229. 
Tryon, C.A., Faith, J.T., Peppe, D.J., Fox, D.L., McNulty, K.P., Jenkins, K., Dunsworth, H., Harcourt-Smith, W., 2010. The Pleistocene archaeology and environments of the Wasiriya Beds, Rusinga Island, Kenya. J. Hum. Evol. 59, 657-671.

Tryon, C.A., Peppe, D.J., Faith, J.T., Van Plantinga, A., Nightengale, S., Ogondo, J., 2012. Late Pleistocene artefacts and fauna from Rusinga and Mfangano islands, Lake Victoria, Kenya. Azania 47, 14-38.

Tryon, C.A., Faith, J.T., Peppe, D.J., Keegan, W.F., Keegan, K.N., Jenkins, K.H., Nightingale, S., Patterson, D., Van Plantinga, A., Driese, S., Johnson, C.R., Beverly, E.J., 2014. Sites on the landscape: paleoenvironmental context of late Pleistocene archaeological sites from the Lake Victoria Basin, equatorial East Africa. Quatern. Int. 331, 20-30.

Tryon, C.A., Crevecoeur, I., Faith, J.T., Ekshtain, R., Nivens, J., Patterson, D., Mbua, E.N., Spoor, F., 2015. Late Pleistocene age and archaeological context for the hominin calvaria from GvJm-22 (Lukenya Hill, Kenya). Proc. Natl. Acad. Sci. USA. doi:10.1073/pnas.1417909112.

Vaks, A., Bar-Matthews, M., Ayalon, A., Matthews, A., Halicz, L., Frumkin, A., 2007. Desert speleothems reveal climatic window for African exodus of early modern humans. Geology 35, 831-834.

van Breugel P., Kindt R., Lillesø J.P.B., Bingham M., Demissew S., Dudley C., Friis I., Gachathi F., Kalema J., Mbago F., Moshi H.N., Mulumba, J., Namaganda M., Ndangalasi H.J., Ruffo C.K., Védaste M., Jamnadass R., Graudal, L.., 2012. Potential Natural Vegetation Map of Eastern Africa: An interactive vegetation map for Ethiopia, Kenya, Malawi, Rwanda, Tanzania, Uganda and Zambia. 
Version 1.1. Forest and Landscape (Denmark) and World Agroforestry Centre (ICRAF). <http://vegetationmap4africa.org.>

Van Couvering, J., 1972. Geology of Rusinga Island and correlation of the Kenya Mid-Tertiary fauna. Ph.D. Thesis, Cambridge University.

Vermeersch, P.M., 2001. "Out of Africa" from an Egyptian point of view. Quatern. Int. $75,103-112$.

Vrba, E.S., 1980. The significance of bovid remains as an indicator of environment and predation patterns. In: Behrensmeyer, A.K., Hill, A.P. (Eds.), Fossils in the Making. University of Chicago Press, Chicago, pp. 247-272.

Walker, A., Teaford, M.F., 1988. The Kaswanga Primate Site: an Early Miocene hominoid site on Rusinga Island, Kenya. J. Hum. Evol. 17, 539-544.

White, F., 1983. The Vegetation of Africa. UNESCO, Paris.

Willoughby, P.R., 2012. The Middle and Later Stone Age in the Iringa Region of southern Tanzania. Quatern. Int. 270, 103-118.

Wronski, T., Hausdorf, B., 2008. Distribution patterns of land snails in Ugandan rain forests support the extistence of Pleistocene forest refugia. J. Biogeogr. 35, $1759-1768$. 


\section{Figure captions}

Figure 1. The location of Karungu and its Pleistocene exposures (following Pickford, 1984) in western Kenya.

Figure 2. Front and back of photograph taken by W.E. Owen in 1935/1936 at Ngira showing the location of human cranial fragments eroding from near the surface of black cotton soils. Source: National Museums of Kenya Archives. The text on the back of the photograph reads as follows: Ng'ira, Karungu site. Tree is west of skull mound, eleven paces. The two fragments of skull seen were weathering out of the mound, just where they are lying. The photograph shows clearly the place about them where I smoothed the soil away with my fingers to see if any more fragments were contiguous. The mound top is indicated by sugar cane stem.

Figure 3. Location of the Aringo 3 excavation and systematic surface crawls at Kisaaka, Obware, and Aringo (see also Table 1). Microfauna screened at Kisaaka Rodent Carbonate Site (RCS), ZTG (Zebra Tooth Gully), and Main.

Figure 4. Stratigraphy of the Pleistocene deposits at Karungu. The "type" stratigraphic section for the Karungu deposits is at Kisaaka (far left). All other Karungu localities have been correlated to Kisaaka based on tephrostratigraphy (solid lines; SOM; see Blegen et al., in review for correlation of upper BPTP tephra) and lithostratigraphy (dashed lines). The widespread Nyamita Tuff has been used as a stratigraphic datum for correlation between sections. Locations of in situ artifacts, mammalian fossils, and the surface collection sites for micromammals and 
systematic surface crawls (Table 1) are indicated on each stratigraphic section. Fauna and diagnostic MSA artifacts were surface-collected from all paleosols and conglomerates at all sites, spanning the Karungu Pleistocene sequence. The geographic locations of each locality are indicated in Figure 1.

Figure 5. Select MSA artifacts from Karungu, including (A) Levallois flake from Aringo, (B), Levallois core from Aringo, and (C) bifacial point from Obware.

Figure 6. Principal components analysis (left PC1 vs. PC2; right PC1 vs. PC3) of major elements and oxides for the obsidian flakes recovered from Karungu (Table 2) and the 77 documented sources in Kenya (average values for each source calculated from Brown et al., 2013). AK $=$ Akira; $B A 1=$ Broad Acres $1 ; B A 2=$ Broad Acres 2; HG1 = Hell's Gate 1; HG2 = Hell's Gate 2; K1 = Kibikoni 1; K2 = Kibikoni 2; $\mathrm{OK}=\mathrm{OI}$ Karia; $\mathrm{O} 1$ = Ololbutot $1 ; \mathrm{O} 2=$ Ololbutot 2; $\mathrm{O}=$ Olenguroni; $\mathrm{M}=$ Mundui .

Figure 7. Left: Buccal (top) and occlusal (bottom) views of a right mandible of Oryx cf. beisa. Right: An articulated cranium and mandible of East African molerat (Tachyoryctes splendens).

Figure 8. The geographic ranges of white rhinoceros (Ceratotherium simum), Grevy's zebra (Equus grevyi), and southern reedbuck (Redunca arundinum; IUCN, 2013; Rookmaaker and Antoine, 2013).

Figure 9. $\delta^{13} \mathrm{C}$ values of surface-collected bovid and rodent teeth from Karungu. A: Dotted line represents $100 \% \mathrm{C}_{4}$ diet based on calculated $\varepsilon^{*}$ enamel-diet; grey box 
represents $\pm 1 \mathrm{SD}$ of the carbon isotopic composition of $\mathrm{C}_{4}$ used to calculate the $\mathrm{C}_{4}$ diet endmember. B: Tachyoryctes splendens enamel carbon isotopic composition and estimated percentage $\mathrm{C}_{4}$ consumption.

Figure 10. Axis 1 and 3 of Principal Coordinates Analysis (PcOA) of artifact assemblage composition for Late Pleistocene MSA sites in East Africa (data from Table 5). Squares correspond to northern sites ( $>5$ degrees latitude) and diamonds correspond to southern sites ( at or below the equator). 


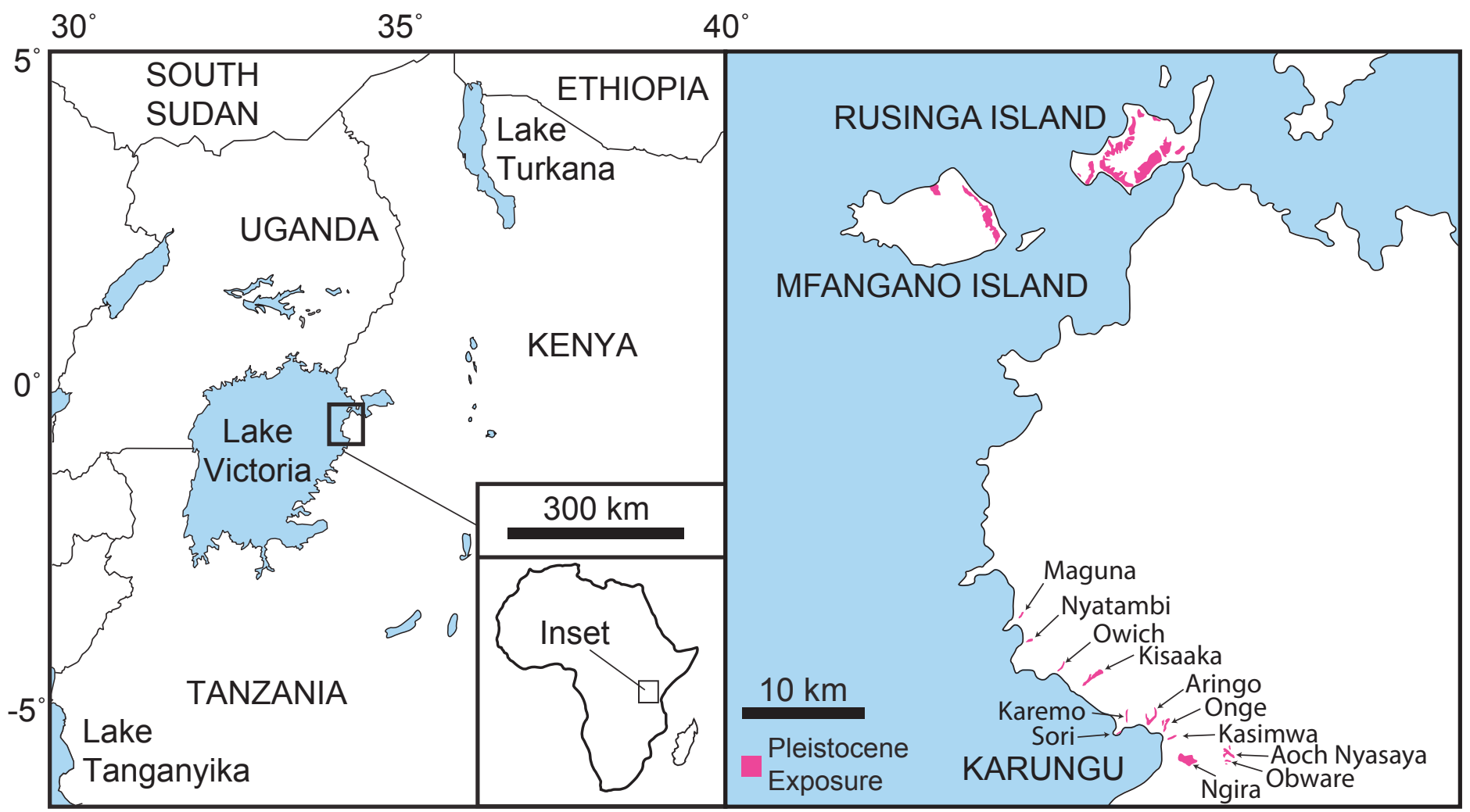


Figure 2

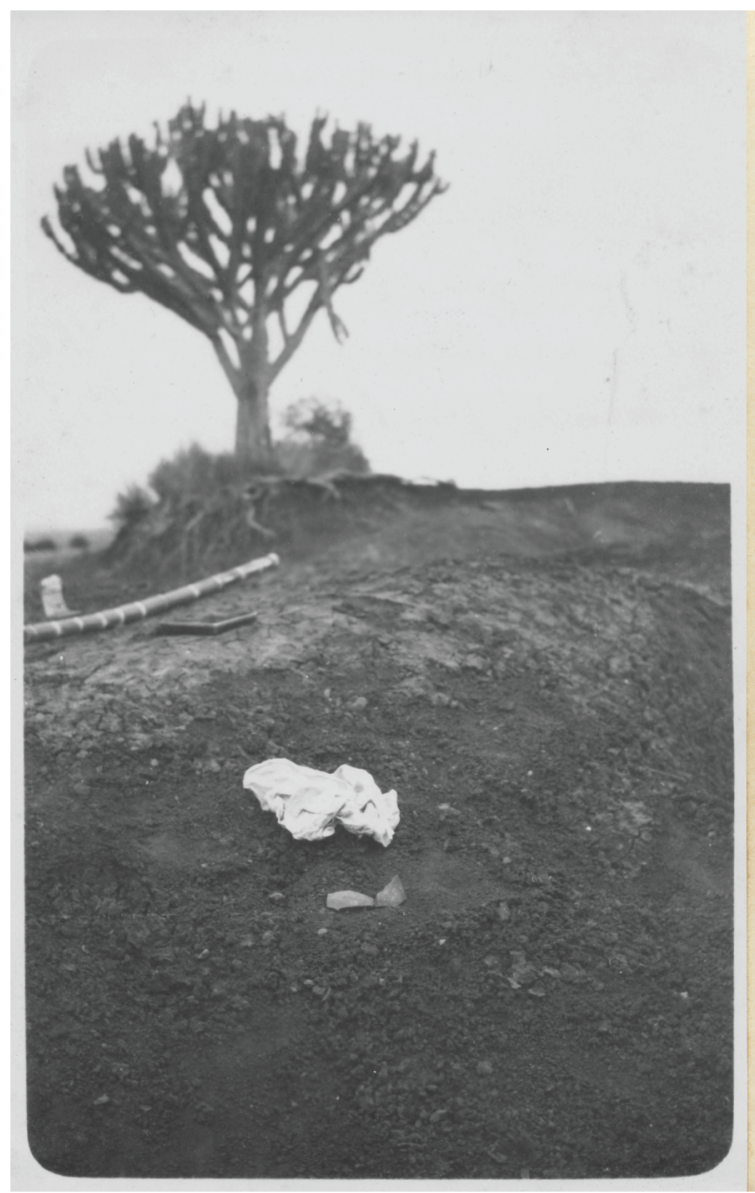

Mgiva, Kareungu sche.

Iree is west of skull mound, elevenf aces. The two fraquents of skich seen were weatherwe ouh of the mound, mat where they arelycies. The photogiogh ahows clemly the flace about then where \& suoveted the soil auray whtiny fugers losee of any cuore fraquents were. contiguous.

The mound lot is molvented by saqar cane rtii. 


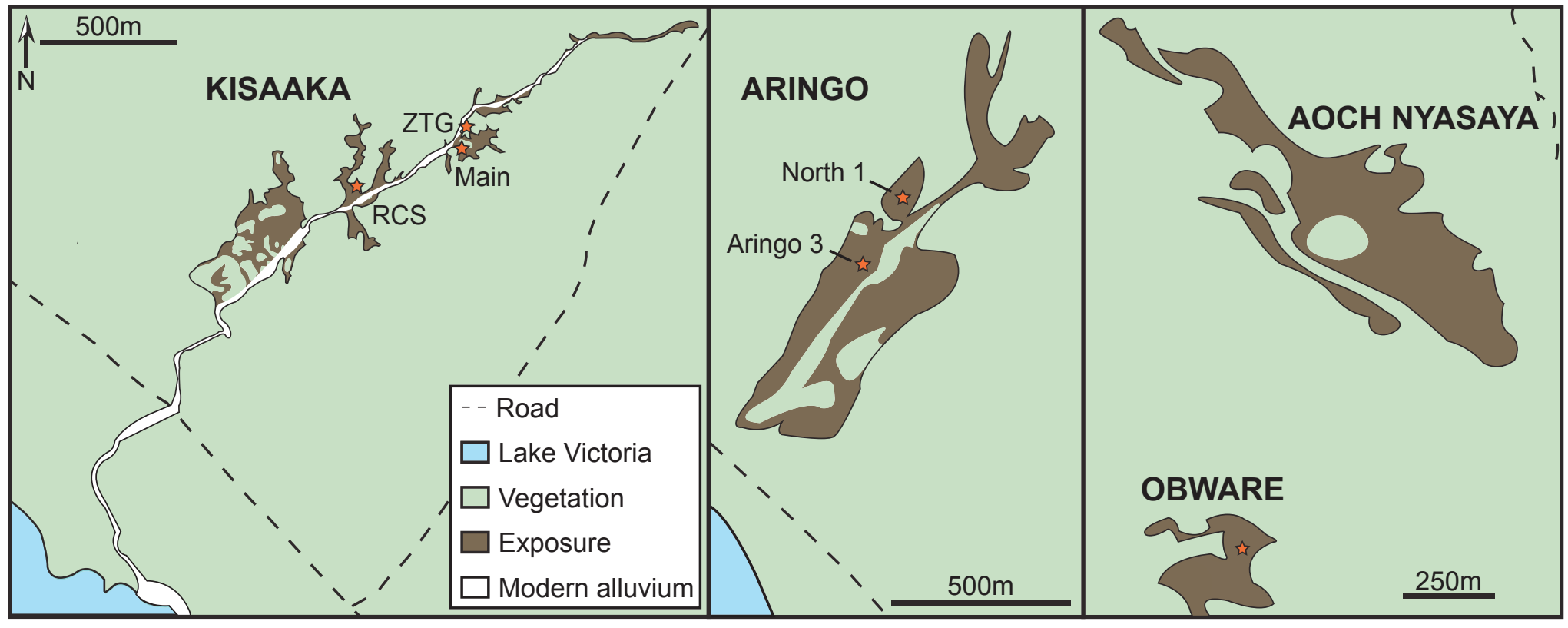




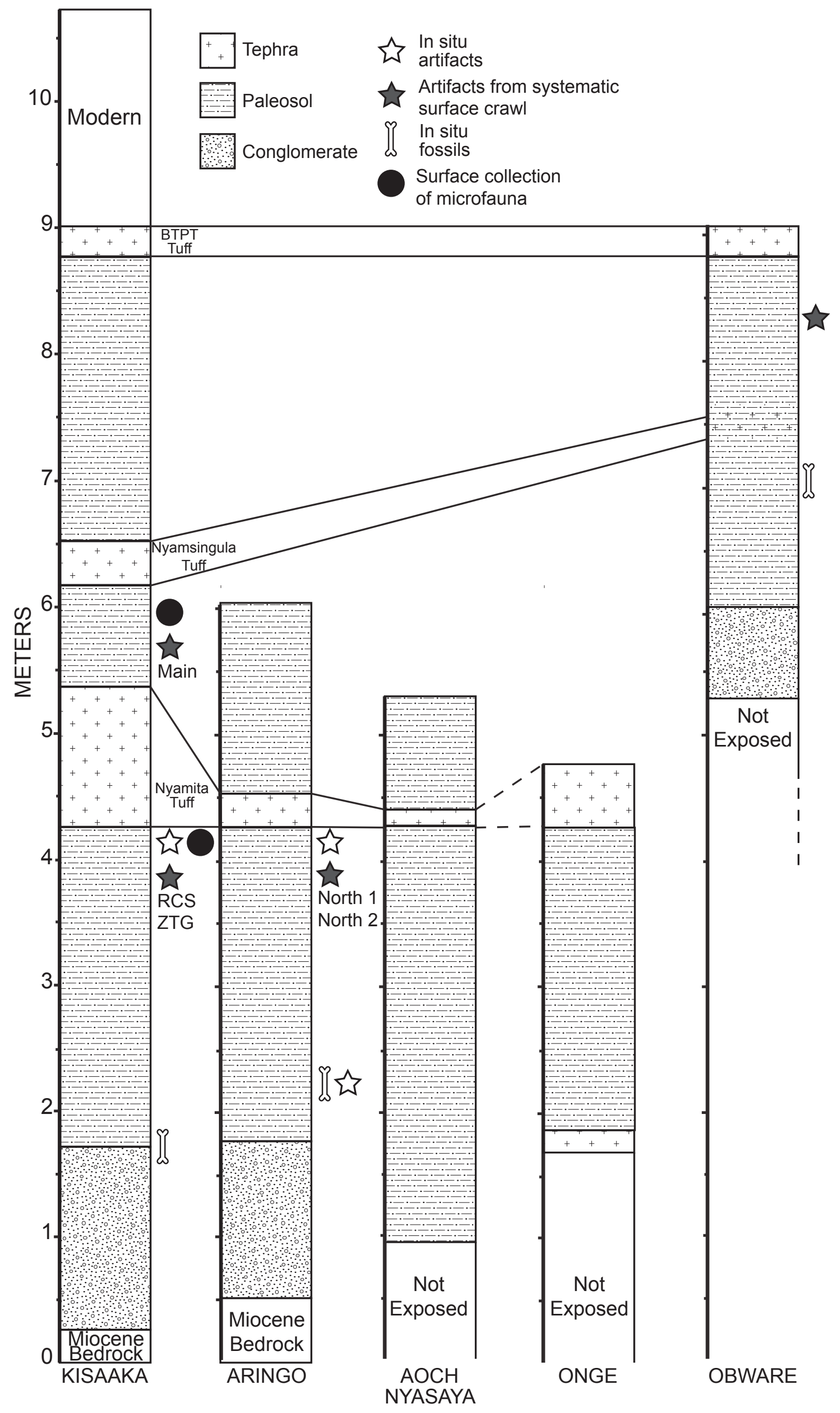


Figure 5
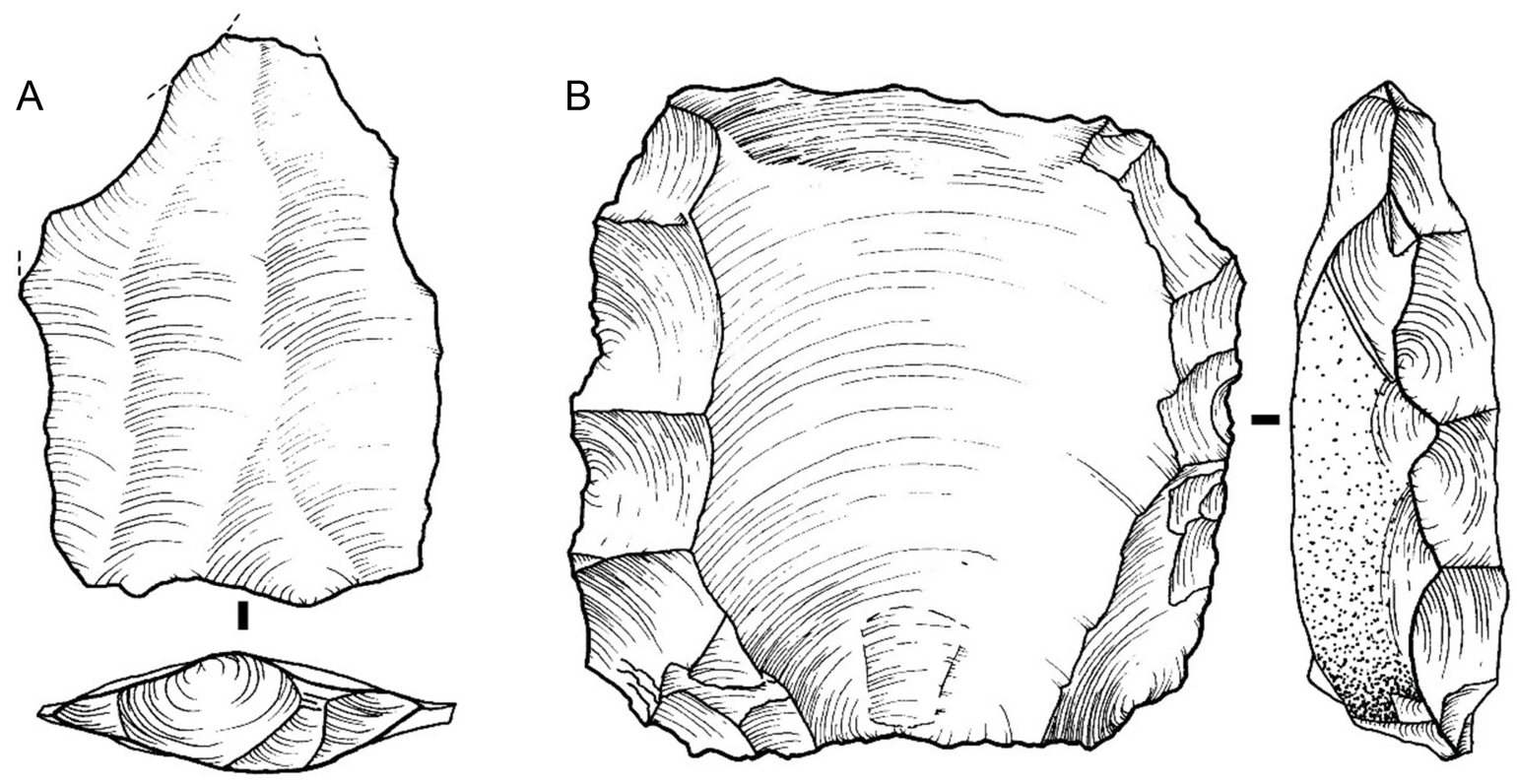

$3 \mathrm{~cm}$

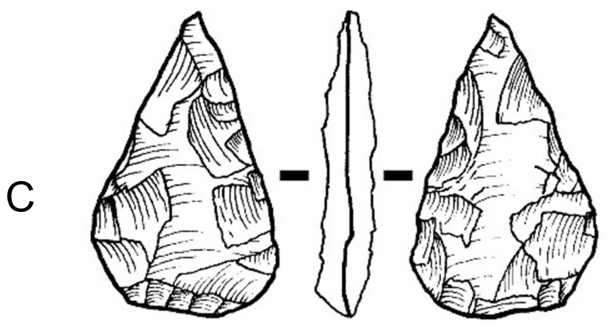



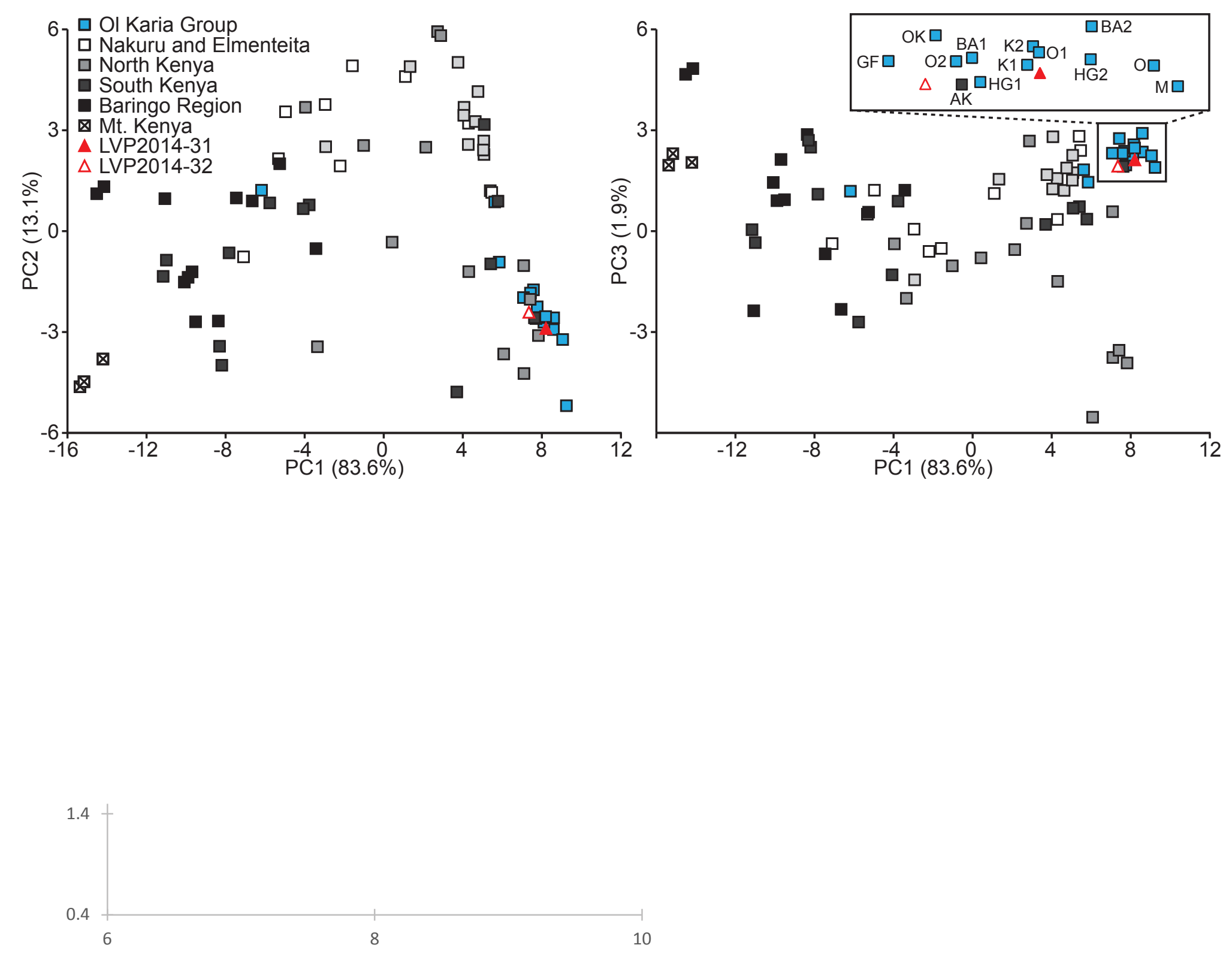

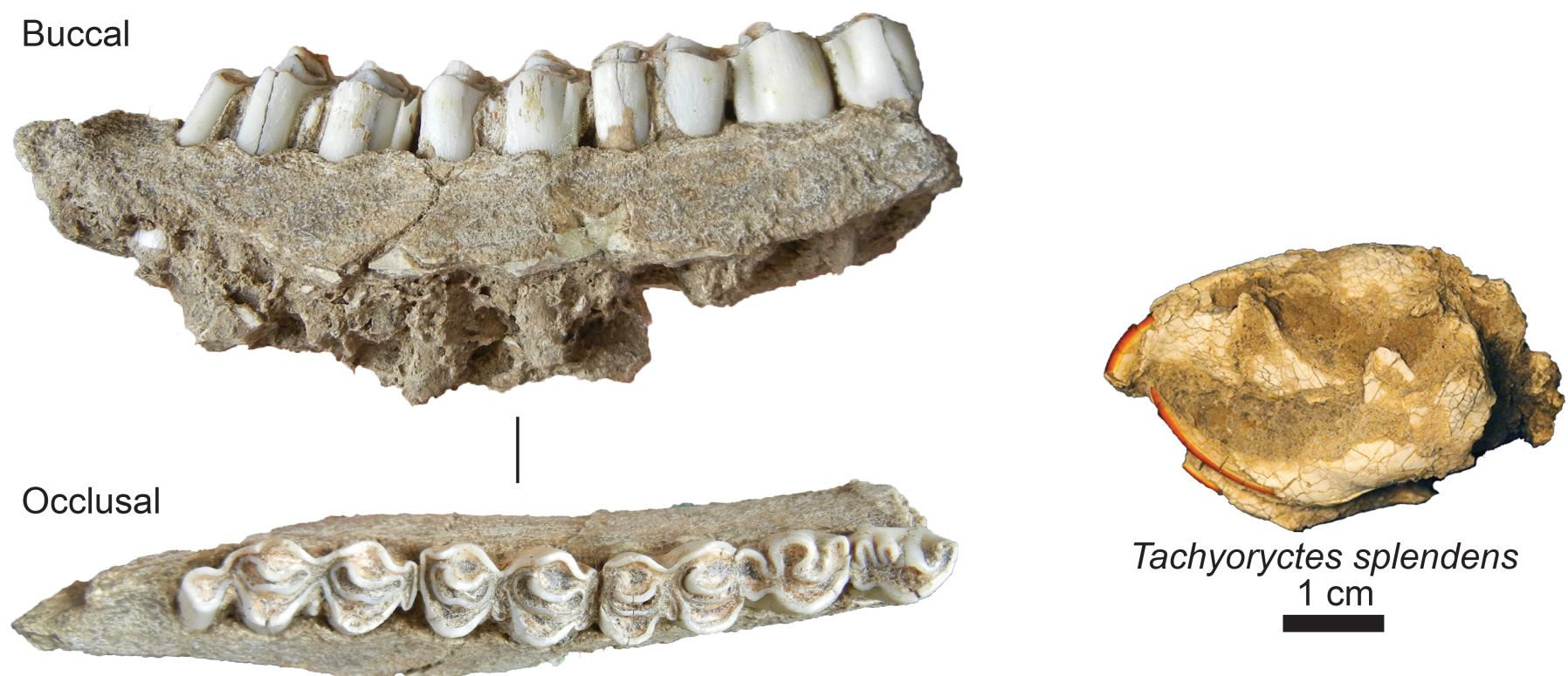

Tachyoryctes splendens $1 \mathrm{~cm}$

Oryx cf. beisa

$5 \mathrm{~cm}$ 
Figure 8

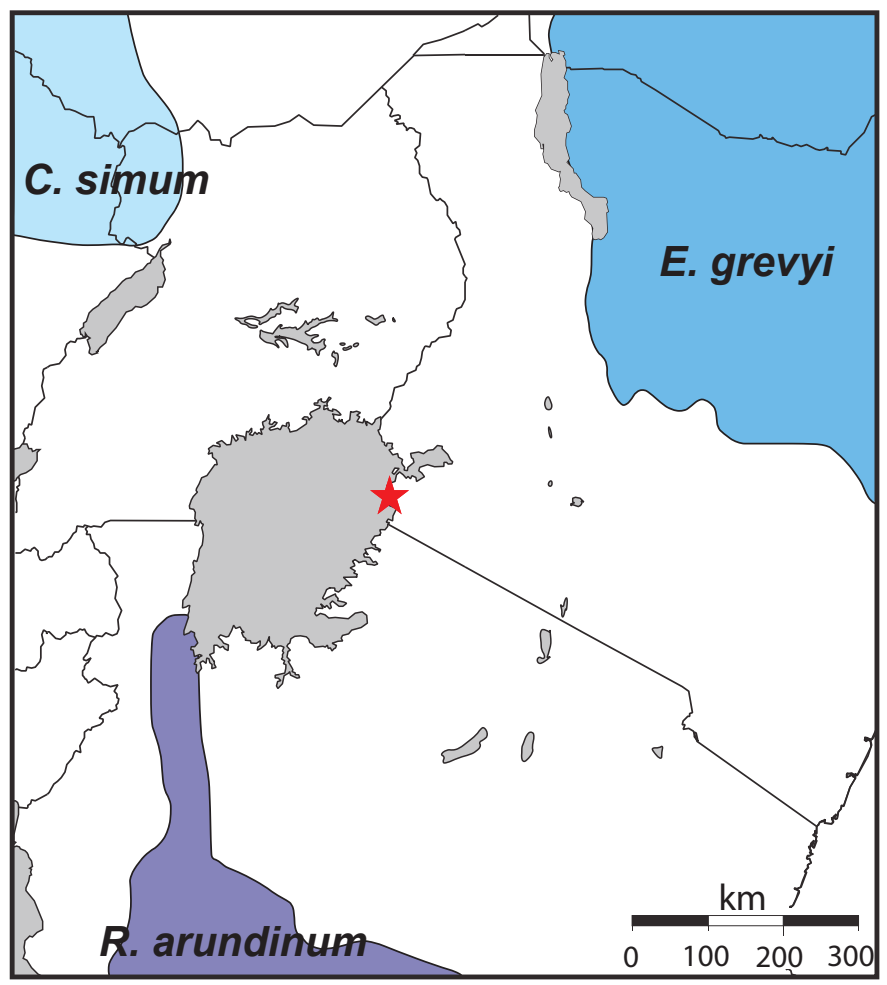


A

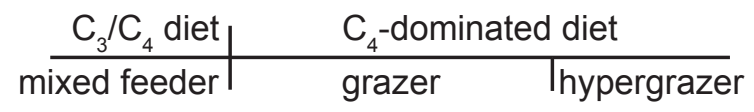

$\delta^{13} \mathrm{C}$ (VPDB) tooth enamel (\%o)

Alcelaphini indet. (2)

cf. Alcelaphus (2)

Damaliscus hyspsodon (4)

cf. Rusingoryx (3)

Gazella thomsoni (1)

Syncerus spp.(5)

Ourebia ourebi (2)

Redunca sp. (1)

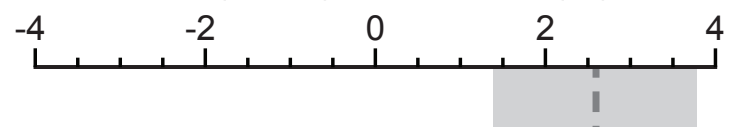

B Tachyoryctes splendens (17)
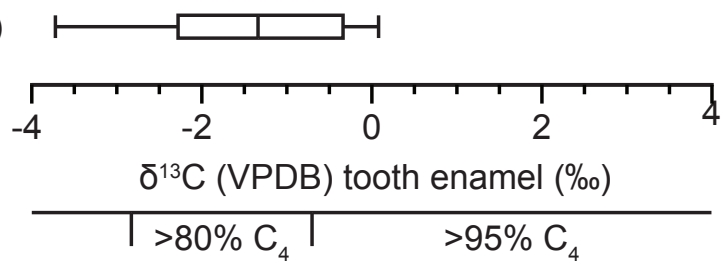


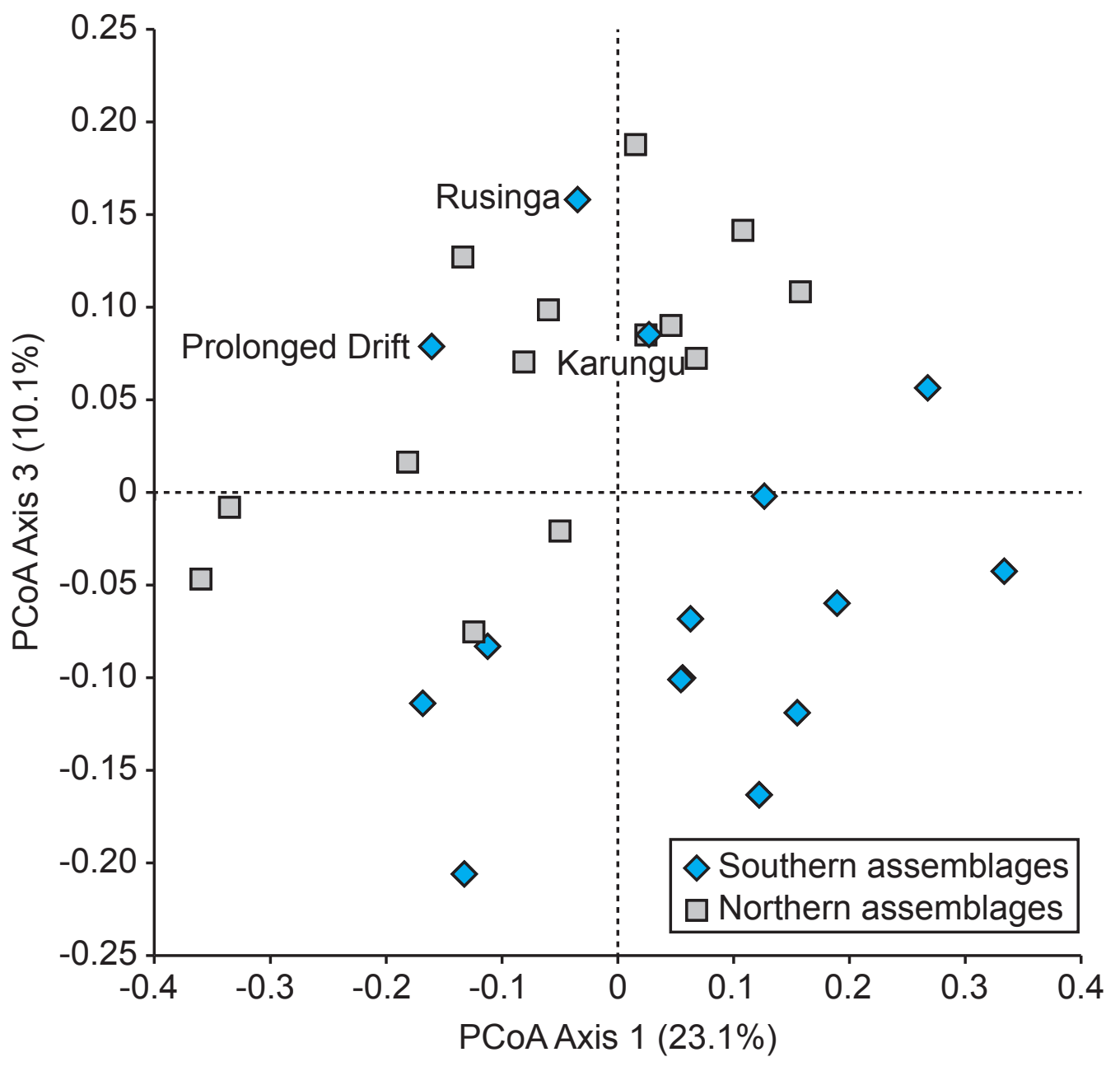


Table 1. Summary of artifacts recovered from survey, the Aringo 3 test excavation, and systematic surface crawls at Aringo,

Kisaaka, and Obware ${ }^{a}$

\begin{tabular}{|c|c|c|c|c|c|c|c|c|}
\hline Site & $\begin{array}{l}\text { General } \\
\text { Survey }\end{array}$ & $\begin{array}{l}\text { Aringo } 3 \\
\text { Excavation }\end{array}$ & $\begin{array}{l}\text { Aringo } \\
\text { North } 1\end{array}$ & $\begin{array}{l}\text { Aringo } \\
\text { North } 2\end{array}$ & $\begin{array}{l}\text { Kisaaka- } \\
\text { ZTG }\end{array}$ & $\begin{array}{l}\text { Kisaaka- } \\
\text { Main }\end{array}$ & $\begin{array}{l}\text { Kisaaka- } \\
\text { RCS }\end{array}$ & Obware \\
\hline Area $\left(m^{2}\right)$ & $\mathrm{N} / \mathrm{A}$ & 5 & 25 & 25 & 25 & 25 & 25 & 24 \\
\hline Complete flakes & $22\left(1^{\star}, 2^{\star \star}\right)$ & $54\left(2^{\star}, 1^{* \star}\right)$ & 4 & 6 & 8 & 6 & 3 & $5\left(1^{\star *}\right)$ \\
\hline Flake fragments & $14\left(2^{*}, 1^{*}\right)$ & $44\left(3^{\star}\right)$ & 11 & 27 & $18\left(2^{* \star}\right)$ & 13 & 6 & $4\left(1^{\star \star}\right)$ \\
\hline Cores & $17\left(10^{*}\right)$ & $4\left(2^{\star}\right)$ & 1 & 0 & $3\left(1^{*}\right)$ & 0 & 0 & $5\left(1^{\star}\right)$ \\
\hline $\begin{array}{l}\text { Retouched } \\
\text { pieces }\end{array}$ & $10\left(1^{\star \star}\right)$ & 0 & 0 & 0 & 0 & $2\left(1^{\star \star}\right)$ & 0 & 0 \\
\hline Handaxe & $1^{\mathrm{b}}$ & 0 & 0 & 0 & 0 & 0 & 0 & 0 \\
\hline Angular waste & 0 & 114 & 0 & 0 & 0 & 0 & 0 & 0 \\
\hline Total & 63 & 216 & 16 & 33 & 29 & 21 & 9 & 14 \\
\hline Artifacts $/ \mathrm{m}^{2}$ & NA & 43.2 & 0.64 & 1.32 & 1.16 & 0.84 & 0.36 & 0.58 \\
\hline
\end{tabular}

a Values in parentheses are *Levallois or **blades

${ }^{\mathrm{b}} \mathrm{A}$ weathered and rolled specimen recovered from a modern alluvial deposit atop the Miocene bedrock at Kisaaka. 
Table 2. Geochemical composition of obsidian fragments from the Aringo 3 excavation (mean $\pm \sigma$ of five measurements)

\begin{tabular}{|c|c|c|c|c|c|c|c|c|c|c|c|c|}
\hline \multirow[t]{2}{*}{ Field \# } & \multicolumn{12}{|c|}{ Major elements (wt \%) } \\
\hline & $\mathrm{SiO}_{2}$ & $\mathrm{TiO}_{2}$ & $\mathrm{ZrO}_{2}$ & $\mathrm{Al}_{2} \mathrm{O}_{3}$ & $\mathrm{Fe}_{2} \mathrm{O}_{3}$ & $\mathrm{MnO}$ & $\mathrm{MgO}$ & $\mathrm{CaO}$ & $\mathrm{Na}_{2} \mathrm{O}$ & $\mathrm{K}_{2} \mathrm{O}$ & $\mathrm{F}$ & $\mathrm{Cl}$ \\
\hline LVP2014-31 & $\begin{array}{l}73.91 \pm \\
0.46\end{array}$ & $\begin{array}{l}0.16 \pm \\
0.05\end{array}$ & $\begin{array}{l}0.26 \pm \\
0.04\end{array}$ & $\begin{array}{l}10.64 \pm \\
0.08\end{array}$ & $\begin{array}{l}3.56 \pm \\
0.06\end{array}$ & $\begin{array}{l}0.05 \pm \\
0.02\end{array}$ & $\begin{array}{l}0.02 \pm \\
0.1\end{array}$ & $\begin{array}{l}0.16 \pm \\
0.03\end{array}$ & $\begin{array}{l}5.21 \pm \\
0.11\end{array}$ & $\begin{array}{l}4.67 \pm \\
0.03\end{array}$ & $\begin{array}{l}0.89 \pm \\
0.03\end{array}$ & $\begin{array}{l}0.36 \pm \\
0.01\end{array}$ \\
\hline LVP2014-32 & $\begin{array}{l}72.93 \pm \\
0.21\end{array}$ & $\begin{array}{l}0.16 \pm \\
0.02\end{array}$ & $\begin{array}{l}0.32 \pm \\
0.04\end{array}$ & $\begin{array}{l}10.35 \pm \\
0.05\end{array}$ & $\begin{array}{l}3.82 \pm \\
0.05\end{array}$ & $\begin{array}{l}0.05 \pm \\
0.01\end{array}$ & $\begin{array}{l}0.02 \pm \\
0.1\end{array}$ & $\begin{array}{l}0.13 \pm \\
0.05\end{array}$ & $\begin{array}{l}5.39 \pm \\
0.16\end{array}$ & $\begin{array}{l}4.65 \pm \\
0.13\end{array}$ & $\begin{array}{l}0.91 \pm \\
0.06\end{array}$ & $\begin{array}{l}0.39 \pm \\
0.02\end{array}$ \\
\hline
\end{tabular}


Table 3. Specimen counts (NISP) for the mammalian fauna recovered from Karungu.

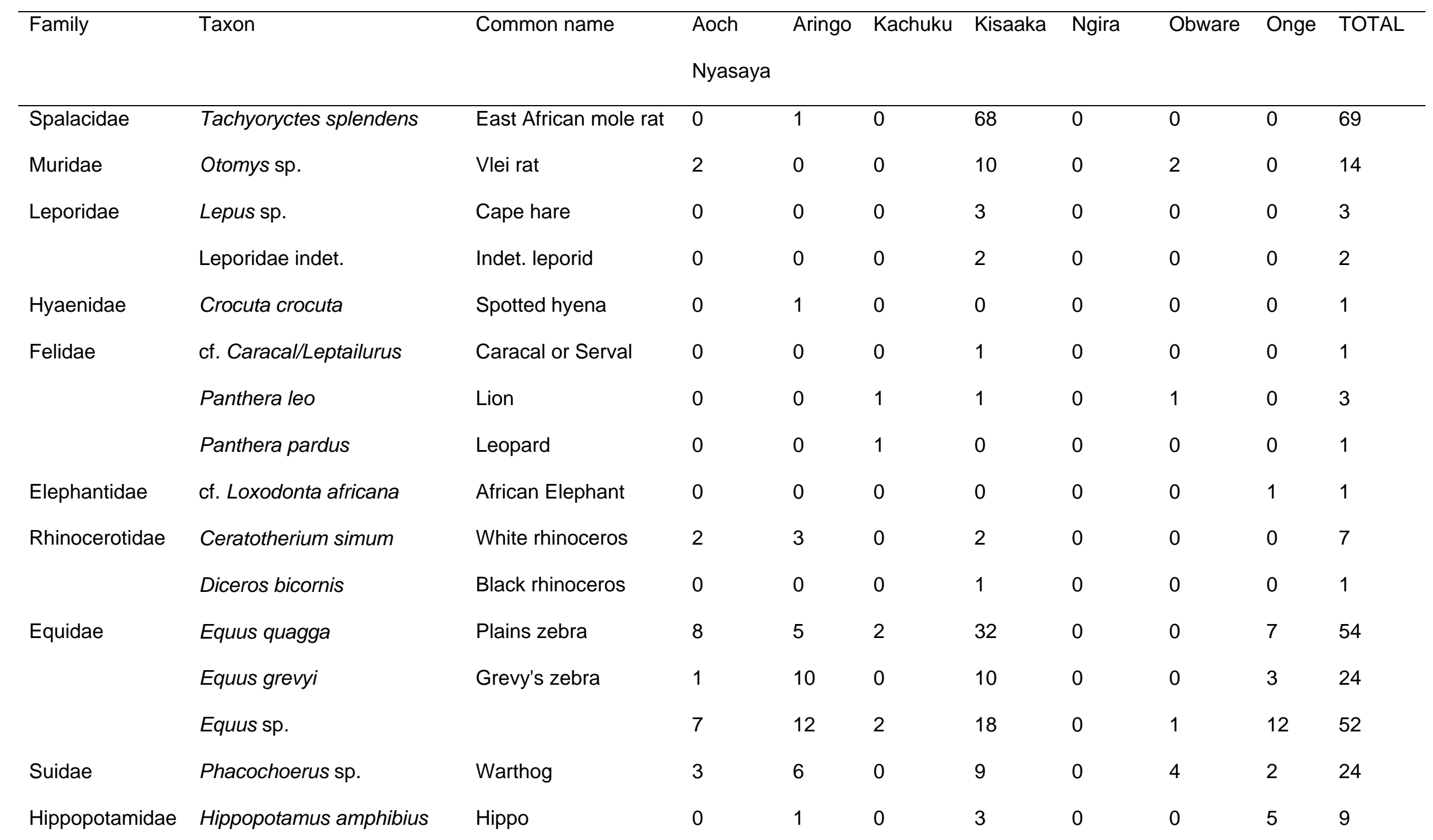




\begin{tabular}{|c|c|c|c|c|c|c|c|c|c|c|}
\hline \multirow[t]{19}{*}{ Bovidae } & Taurotragus oryx & Eland & 1 & 0 & 0 & 3 & 0 & 0 & 0 & 4 \\
\hline & Tragelaphus scriptus & Bushbuck & 0 & 2 & 0 & 2 & 0 & 0 & 0 & 4 \\
\hline & Tragelaphini indet. & Eland or kudu & 0 & 0 & 0 & 2 & 0 & 0 & 0 & 2 \\
\hline & Oryx cf. beisa & Oryx & 1 & 0 & 1 & 8 & 1 & 1 & 0 & 12 \\
\hline & Hippotragini indet. & & 0 & 0 & 0 & 1 & 0 & 0 & 0 & 1 \\
\hline & Redunca arundinum & Southern reedbuck & 0 & 0 & 0 & 1 & 0 & 0 & 0 & 1 \\
\hline & Redunca arundinum/Kobus & Southern reedbuck & 0 & 1 & 0 & 3 & 0 & 0 & 0 & 4 \\
\hline & $k o b$ & or kob & & & & & & & & \\
\hline & Redunca cf. redunca & Reedbuck & 1 & 0 & 0 & 0 & 0 & 0 & 0 & 1 \\
\hline & Alcelaphus buselaphus & Hartebeest & 1 & 7 & 0 & 17 & 0 & 0 & 1 & 26 \\
\hline & Connochaetes taurinus & Wildebeest & 1 & 6 & 0 & 18 & 0 & 0 & 2 & 27 \\
\hline & Damaliscus hypsodon ${ }^{\mathrm{b}}$ & Extinct blesbok & 6 & 13 & 0 & 12 & 0 & 0 & 8 & 39 \\
\hline & Megalotragus sp. ${ }^{\mathrm{b}}$ & Giant wildebeest & 1 & 4 & 0 & 3 & 0 & 0 & 1 & 9 \\
\hline & Rusingoryx atopocranion ${ }^{b}$ & Extinct wildebeest & 5 & 12 & 0 & 49 & 0 & 0 & 3 & 69 \\
\hline & Alcelaphini indet. & & 1 & 9 & 0 & 28 & 0 & 2 & 5 & 45 \\
\hline & Gazella granti & Grant's gazelle & 0 & 1 & 0 & 0 & 0 & 0 & 0 & 1 \\
\hline & Gazella thomsoni & Thomson's gazelle & 2 & 2 & 0 & 7 & 0 & 5 & 1 & 17 \\
\hline & Antilopini indet. & & 0 & 0 & 0 & 2 & 0 & 0 & 0 & 2 \\
\hline & Aepyceros sp. nov. ${ }^{\mathrm{b}}$ & Extinct impala & 1 & 0 & 0 & 0 & 0 & 0 & 0 & 1 \\
\hline
\end{tabular}




\begin{tabular}{|c|c|c|c|c|c|c|c|c|c|}
\hline Syncerus antiquus ${ }^{b}$ & Long-horn buffalo & 5 & 1 & 0 & 5 & 0 & 0 & 0 & 11 \\
\hline Syncerus caffer & African buffalo & 2 & 5 & 1 & 16 & 0 & 0 & 2 & 26 \\
\hline Syncerus sp. & & 0 & 1 & 0 & 0 & 0 & 0 & 0 & 1 \\
\hline Ourebia ourebi & Oribi & 0 & 1 & 0 & 3 & 0 & 0 & 1 & 5 \\
\hline & $\Sigma N I S P$ & 51 & 104 & 8 & 340 & 1 & 16 & 54 & 574 \\
\hline
\end{tabular}

${ }^{b}$ Extinct 
Table 4. Stable isotopic composition $\left(\delta^{13} \mathrm{C}\right.$ VPDB and $\delta^{18} \mathrm{O}$ VPDB) of tooth enamel from Karungu bovids and rodents ${ }^{a}$

\begin{tabular}{|c|c|c|c|c|c|}
\hline Field No & Tribe & Taxon & $\delta^{13} \mathrm{C}(\mathrm{VPDB})$ & $\% \mathrm{C}_{4}$ & $\delta^{18} \mathrm{O}(\mathrm{VPDB})$ \\
\hline KAR13-76 & Alcelaphini & cf. Alcelaphus buselaphus & 2.1 & 96 & -0.2 \\
\hline KAR13-76 & Alcelaphini & cf. Alcelaphus buselaphus & 1.9 & 95 & -1.3 \\
\hline KAR13-81 & Alcelaphini & cf. Rusingoryx atopocranion & 0.7 & 87 & -1.2 \\
\hline KAR13-32 & Alcelaphini & cf. Rusingoryx atopocranion & 1.1 & 90 & 0.8 \\
\hline KAR13-42 & Alcelaphini & cf. Rusingoryx atopocranion & -0.5 & 79 & -0.9 \\
\hline KAR13-176 & Alcelaphini & Damaliscus hypsodon & 2.7 & 100 & 0.1 \\
\hline KAR13-137 & Alcelaphini & Damaliscus hypsodon & 2.7 & 100 & 0.7 \\
\hline KAR13-175 & Alcelaphini & Damaliscus hypsodon & 2.2 & 97 & -0.7 \\
\hline KAR13-172 & Alcelaphini & Damaliscus hypsodon & 2.5 & 99 & 0.1 \\
\hline KAR13-173 & Alcelaphini & Alcelaphini indet. & 2.4 & 98 & 1.8 \\
\hline KAR13-47 & Alcelaphini & Alcelaphini indet. & 1.7 & 94 & -2.6 \\
\hline KAR13-68 & Antilopini & Gazella thomsoni & -0.9 & 77 & 1.1 \\
\hline KAR13-136 & Bovini & Syncerus antiquus & 2.0 & 96 & -1.8 \\
\hline KAR13-168 & Bovini & Syncerus antiquus & 0.1 & 83 & -1.1 \\
\hline KAR13-159 & Bovini & Syncerus caffer & -0.2 & 81 & -1.6 \\
\hline KAR13-64 & Bovini & Syncerus caffer & 3.2 & 100 & 0.3 \\
\hline KAR13-161 & Bovini & Syncerus caffer & -0.7 & 78 & -1.8 \\
\hline KAR13-185 & Neotragini & Ourebia ourebi & 1.8 & 94 & 1.4 \\
\hline KAR13-186 & Neotragini & Ourebia ourebi & 2.6 & 100 & 0.4 \\
\hline KAR13-184 & Reduncini & Redunca cf. redunca & 2.3 & 98 & -0.2 \\
\hline KR13-13 & & Tachyoryctes splendens & -0.6 & 96 & -0.7 \\
\hline KR13-14 & & Tachyoryctes splendens & -2.2 & 85 & -2.7 \\
\hline KR13-17 & & Tachyoryctes splendens & -2.5 & 83 & 0.7 \\
\hline KR13-18 & & Tachyoryctes splendens & -0.2 & 99 & -0.2 \\
\hline KR13-19 & & Tachyoryctes splendens & -0.4 & 98 & -1.4 \\
\hline KR13-31 & & Tachyoryctes splendens & 0.1 & 100 & -0.2 \\
\hline KR13-36 & & Tachyoryctes splendens & -1.4 & 90 & -0.8 \\
\hline
\end{tabular}




\begin{tabular}{lllll} 
KR13-37 & Tachyoryctes splendens & -2.9 & 80 & -1.4 \\
KR13-38 & Tachyoryctes splendens & -2.2 & 85 & -1.2 \\
KR13-41 & Tachyoryctes splendens & -0.6 & 96 & -0.7 \\
KR13-43 & Tachyoryctes splendens & -2.3 & 84 & -1.1 \\
KR13-52 & Tachyoryctes splendens & -3.8 & 74 & -0.9 \\
KR13-75 & Tachyoryctes splendens & -0.7 & 95 & -1.2 \\
KR13-82-1 & Tachyoryctes splendens & -2.6 & 83 & 0.0 \\
KR13-82-2 & Tachyoryctes splendens & -0.3 & 98 & -1.2 \\
KR13-82-3 & Tachyoryctes splendens & -0.1 & 99 & -1.1 \\
KR13-84 & Tachyoryctes splendens & -1.3 & 91 & 0.5 \\
\hline
\end{tabular}

a Percent contribution of $\mathrm{C}_{4}$ resources to the diet is estimated using an an isotope enrichment $\left(\varepsilon^{*}\right)$ between diet and tooth enamel of $14.1 \%$ and $11.0 \%$ for bovids and rodents, respectively. 
Table 5. Artifact assemblage composition across East African MSA sites (from Tryon and Faith, 2013).

\begin{tabular}{|c|c|c|c|c|c|c|c|c|c|c|c|c|c|c|c|c|}
\hline \multirow[b]{2}{*}{ Locality } & \multirow[b]{2}{*}{ Latitude } & \multirow[b]{2}{*}{ Longitude } & \multicolumn{14}{|c|}{ Artifact type } \\
\hline & & & $\overline{\frac{3}{4}}$ & $\begin{array}{l}0 \\
\frac{0}{0} \\
\frac{0}{0} \\
.0 \\
.0 \\
0\end{array}$ & $\begin{array}{l}0 \\
0 \\
0 \\
\frac{\xi}{0} \\
0 \\
\frac{\pi}{\alpha}\end{array}$ & $\begin{array}{l}\frac{0}{0} \\
\frac{0}{0} \\
\frac{\pi}{0} \\
\overline{0} \\
.0 \\
\frac{.0}{0}\end{array}$ & 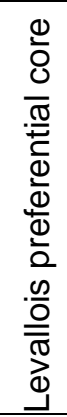 & 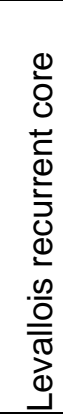 & 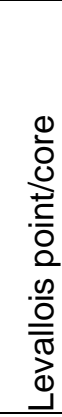 & $\begin{array}{l}0 \\
\overline{0} \\
\overline{0} \\
\frac{\pi}{0} \\
\frac{0}{0}\end{array}$ & $\begin{array}{l}0 \\
\frac{\delta}{0} \\
\frac{\pi}{0}\end{array}$ & 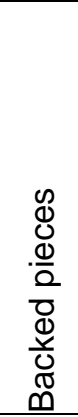 & 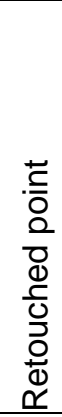 & 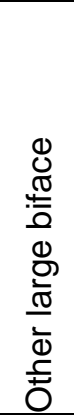 & 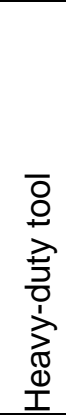 & 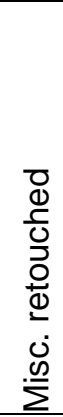 \\
\hline Magubike MSA & -7.8 & 35.5 & $?$ & 1 & 1 & 1 & 0 & $?$ & 0 & 1 & $?$ & 1 & 1 & 0 & $?$ & 1 \\
\hline Mtongwe, Locality KY-55 East, & -4.08 & 39.13 & 0 & 0 & 1 & 1 & $?$ & 0 & 0 & 0 & 1 & 1 & 0 & 0 & 0 & 1 \\
\hline \multicolumn{17}{|l|}{ Upper Group ${ }^{a}$} \\
\hline Mtongwe, Locality KY-55 East, & -4.08 & 39.13 & 0 & 0 & 1 & 1 & $?$ & $?$ & 0 & 1 & 1 & 1 & 0 & 0 & 0 & 1 \\
\hline \multicolumn{17}{|l|}{ Middle Group ${ }^{a}$} \\
\hline Mtongwe, Locality KY-55 East, & -4.08 & 39.13 & 0 & 0 & 1 & 1 & 1 & 1 & 0 & 0 & $?$ & 1 & 0 & 0 & 1 & 1 \\
\hline \multicolumn{17}{|l|}{ Lower Group ${ }^{a}$} \\
\hline Mumba Bed III lower (Nasera & -3.53 & 35.32 & 1 & 1 & 1 & 1 & 1 & $?$ & $?$ & 1 & 1 & 1 & 1 & 0 & 1 & 1 \\
\hline \multicolumn{17}{|l|}{ Industry) } \\
\hline Mumba Bed V (Mumba & -3.53 & 35.32 & 1 & 1 & 1 & 1 & 1 & $?$ & $?$ & 1 & 1 & 1 & 1 & 0 & 0 & 1 \\
\hline
\end{tabular}


Mumba Bed VI-A (Kisele

$-3.53$

Industry)

Mumba Bed VI-B (Sanzako

Industry)

Nasera levels 6-7 (Nasera

Industry)

Nasera levels 8/9-11 (Mumba

Industry)

Nasera levels 12-25 (Kisele

Industry)

Karungu ${ }^{\mathrm{a}}$

Prolonged Drift (GrJi11)

Wasirya Beds, Rusinga Island ${ }^{a}$

Muguruk Formation, Member 4, 0.08

Pundo Makwar Industrya

Muguruk Formation, Member 6, 0.08

Pundo Makwar Industrya

Kibish Formation, Member II/III, 5.41 site BNS ${ }^{a}$ $\begin{array}{lllllllllllllll}35.32 & 1 & 0 & 1 & 1 & 1 & ? & 1 & 1 & 1 & 1 & 1 & 0 & 1 & 1\end{array}$

$\begin{array}{lllllllllllllll}35.32 & 0 & 0 & 1 & 1 & 1 & ? & 0 & 1 & ? & 0 & 1 & 1 & 1 & 1\end{array}$

$\begin{array}{lllllllllllllll}35.36 & 1 & 1 & 1 & 1 & 1 & ? & ? & 1 & 1 & 1 & 1 & 0 & 1 & 1\end{array}$

$\begin{array}{lllllllllllllll}35.36 & 1 & 0 & 1 & 1 & 1 & ? & ? & 0 & 1 & 1 & 1 & 0 & 0 & 1\end{array}$

$\begin{array}{lllllllllllllll}35.36 & 1 & 0 & 1 & 1 & 1 & 1 & 1 & 1 & 1 & 1 & 1 & 0 & 1 & 1\end{array}$

$\begin{array}{lllllllllllllll}34.16 & 0 & 0 & 1 & 1 & 1 & 1 & 1 & 1 & 1 & 0 & 1 & 0 & 0 & 1\end{array}$

$\begin{array}{lllllllllllllll}36.1 & 0 & 0 & 1 & 0 & ? & 0 & ? & 0 & 0 & 0 & 1 & 0 & 0 & 1\end{array}$

$\begin{array}{lllllllllllllll}34.17 & 0 & 0 & 1 & 1 & 1 & 1 & 1 & 0 & 1 & 0 & 1 & 0 & 0 & 1\end{array}$

$\begin{array}{lllllllllllllll}34.63 & 1 & 0 & 1 & 1 & 1 & ? & 1 & 0 & 0 & 0 & 1 & 0 & 1 & 1\end{array}$

$\begin{array}{lllllllllllllll}34.63 & 1 & 0 & 1 & 1 & 1 & 1 & 1 & 0 & 0 & 0 & ? & 0 & 1 & 1\end{array}$

35.9 


\begin{tabular}{|c|c|c|c|c|c|c|c|c|c|c|c|c|c|c|c|c|}
\hline Mochena Borago S-group & 6.9 & 37.76 & 0 & $?$ & 1 & 0 & 1 & 0 & 1 & 1 & 1 & 1 & 1 & 0 & 0 & 1 \\
\hline $\begin{array}{l}\text { Mochena Borago Upper T- } \\
\text { group }\end{array}$ & 6.9 & 37.76 & 0 & $?$ & 1 & 1 & 1 & 0 & 1 & 0 & 1 & 1 & 1 & 0 & 0 & 1 \\
\hline $\begin{array}{l}\text { Mochena Borago Lower T- } \\
\text { group }\end{array}$ & 6.9 & 37.76 & 0 & $?$ & 1 & 1 & 1 & $?$ & 0 & 0 & 1 & 0 & 1 & 0 & 0 & 1 \\
\hline Porc Epic & 9.63 & 41.87 & 0 & 1 & 0 & 1 & 1 & 1 & 1 & 0 & 1 & 1 & 1 & 0 & 0 & 1 \\
\hline $\begin{array}{l}\text { Shelter 7, Laas Geel (SU709- } \\
711 \text { ) }\end{array}$ & 9.7 & 44.3 & $?$ & $?$ & 1 & 0 & 1 & 1 & 1 & 1 & 1 & 1 & 0 & 0 & 0 & 1 \\
\hline Goda Buticha Lower Complex & 10.42 & 40.52 & $?$ & 1 & 1 & 1 & 1 & $?$ & 1 & 0 & 1 & 0 & 1 & 1 & 0 & 1 \\
\hline $\begin{array}{l}\text { Ardu Beds B/C contact, Aduma } \\
\text { site A5a }\end{array}$ & 10.42 & 40.52 & $?$ & 1 & 1 & 1 & 1 & $?$ & 1 & 0 & 1 & 0 & 1 & 1 & 0 & 1 \\
\hline $\begin{array}{l}\text { Ardu Beds B, Aduma sites A4, } \\
\text { A8, A8A, VP 1/1, VP 1/3a }\end{array}$ & 10.42 & 40.52 & 0 & 1 & 1 & 1 & 1 & $?$ & 1 & 0 & 0 & 0 & 1 & 1 & 0 & 1 \\
\hline $\begin{array}{l}\text { Ardu Beds B (base), Aduma } \\
\text { site } A 1^{\text {a }}\end{array}$ & 10.42 & 40.52 & 0 & 0 & 0 & 1 & 1 & $?$ & 0 & 0 & 1 & 0 & 1 & 1 & 0 & 1 \\
\hline Midhishi 2 LSU III & 10.95 & 47.37 & 0 & 0 & 1 & 1 & 1 & $?$ & 1 & 0 & 1 & 1 & 1 & 1 & 1 & 1 \\
\hline Midhishi 2 LSU IV & 10.95 & 47.37 & 0 & 0 & 1 & 0 & 1 & $?$ & 1 & 0 & $?$ & 0 & 1 & 1 & 1 & 1 \\
\hline Midhishi 2 LSU V & 10.95 & 47.37 & 0 & 0 & 1 & 0 & 0 & $?$ & 1 & 0 & $?$ & 0 & 1 & 1 & 1 & 1 \\
\hline Midhishi 2 LSU VI & 10.95 & 47.37 & 0 & 0 & 1 & 1 & 1 & $?$ & 1 & 0 & $?$ & 1 & 1 & 1 & 1 & 1 \\
\hline
\end{tabular}

a Indicates open-air assemblages. 